\title{
Data report: microbial diversity in sediment near Grizzly Bare Seamount in Holes U1363B and U1363G ${ }^{1}$
}

\author{
Sean P. Jungbluth ${ }^{2}$, , Lani G.H. Johnson ${ }^{4}$, James P. Cowen ${ }^{3}$, and Michael S. Rappé2
}

\section{Chapter contents}

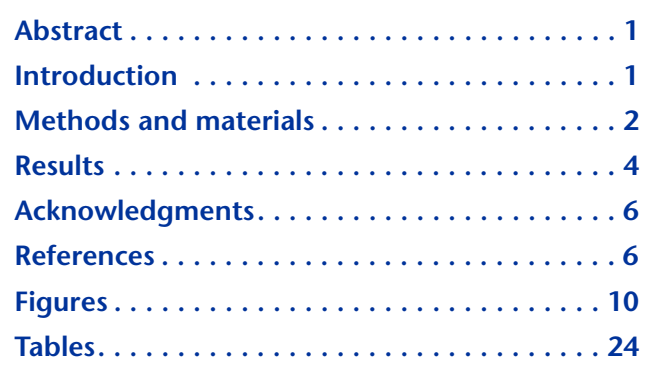

1Jungbluth, S.P., Johnson, L.G.H., Cowen, J.P., and Rappé, M.S., 2013. Data report: microbial diversity in sediment near Grizzly Bare Seamount in Holes U1363B and U1363G. In Fisher, A.T., Tsuji, T., Petronotis, K., and the Expedition 327 Scientists, Proc. IODP, 327: Tokyo (Integrated Ocean Drilling Program Management International, Inc.). doi:10.2204/iodp.proc.327.201.2013

${ }^{2}$ Hawaii Institute of Marine Biology, SOEST, University of Hawaii, PO Box 1346, Kaneohe HI 96744, USA. Correspondence author: jungbluth.sean@gmail.com

${ }^{3}$ Department of Oceanography, SOEST, University of Hawaii, 1000 Pope Road, Honolulu HI 96822, USA.

${ }^{4}$ Marine Science Program, University of Hawaii, 2450 Campus Road, Honolulu HI 96822, USA.

\section{Abstract}

Microorganisms inhabiting sediment in close proximity to recharging basement outcrops are of interest because of the enhanced advective fluid flow in these locations, which is expected to exert unique selective pressures on the resident microbial communities. Here, Integrated Ocean Drilling Program (IODP) boreholes were used to access sediment microbial communities near Grizzly Bare recharge seamount on the Juan de Fuca Ridge eastern flank. The two locations examined in this study, Holes U1363G and U1363B, are 50 and $177 \mathrm{~m}$ away from the center of the outcrop, respectively. In general, small subunit ribosomal RNA gene clones from all three domains of life were detected; these groups were predominantly related to microorganisms known to reside in marine sediment. A large fraction of environmental gene clones recovered from Hole U1363B and U1363G sediment were related to uncultivated, candidate phyla of Bacteria such as BHI80-139, BRC1, JS1, OPB41, and TA06. Hole U1363B and U1363G sediment clone libraries were generally dominated by the domain Bacteria and particularly the phylum Chloroflexi, which comprised approximately one-quarter of the total gene clones identified. However, borehole sediment also contained several archaeal lineages that were phylogenetically affiliated with the Miscellanenous Crenarchaeotal Group. Eukaryotic fungi were only detected within the interstitial water sample from Hole U1363B. Finally, a minor portion of clones recovered from sediment in this study were also recovered from basement fluid samples previously characterized from Baby Bare discharge seamount and Ocean Drilling Program and IODP borehole Circulation Obviation Retrofit Kit Observatories (CORKs) in Holes 1026B and U1301A, which are $\sim 50 \mathrm{~km}$ to the north-northeast.

\section{Introduction}

For more than two decades, Ocean Drilling Program (ODP) and Integrated Ocean Drilling Program (IODP) expeditions to the eastern flank of the Juan de Fuca Ridge have been conducted for the purpose of describing the hydrogeological, geochemical, and microbiological processes and properties within a young ridge flank environment (e.g., Shipboard Scientific Party, 1992, 1997; Expedition 301 Scientists, 2005; Wheat et al., 2013; also see the "Expedition 327 summary" chapter [Expedition 327 Scientists, 
2011a]). Driven by lithospheric cooling of the ridge flank, the porous and permeable igneous ocean basement acts as a subsurface conduit for hydrothermal fluid flow between exposed rocky outcrops (Wheat et al., 2013). Although the nature of microbial life in the sediment-covered basement is the focus of much active research on the Juan de Fuca Ridge, the microbial diversity within marine sediment is still poorly cataloged, due in large part to the restriction of most marine sediment diversity surveys to shallow depths $(<1 \mathrm{~m})$ and continental margins (Orcutt et al., 2011a).

Microbial diversity surveys on the Juan de Fuca Ridge have focused at diffuse flow hydrothermal vents at Axial Seamount (e.g., Lynch, 2000; Alain et al., 2002; Pagé et al., 2004; Huber et al., 2006a, 2009; Kaye et al., 2011; Meyer et al., 2013), high-temperature hydrothermal vents at Endeavor Segment (e.g., Wang et al., 2009a, 2009b; Zhou et al., 2009; Anderson et al., 2013), a hydrothermal mound located at off-axis Cleft Segment (Davis et al., 2009), seafloor basalt (Mason et al., 2007, 2009), sediment-buried basement fluid (Cowen et al., 2003; Huber et al., 2006b; Nakagawa et al., 2006; Jungbluth et al., 2013), and sediment-buried rock (Orcutt et al., 2011b; Smith et al., 2011; Lever et al., 2013). The limited number of microbiological studies focused on sediment of the Juan de Fuca Ridge have typically not incorporated phylogenetic marker-based surveys of community diversity such as small subunit ribosomal RNA (SSU rRNA) gene sequencing (e.g., Cragg et al., 2000; Mather and Parkes, 2000; Engelen et al., 2008); only studies focused on Cascadia margin methane hydrate-bearing sediment have incorporated such an approach (e.g., Bidle et al., 1999; Marchesi et al., 2001; Knittel et al., 2003; Inagaki et al., 2006; Nunoura et al., 2008; Briggs et al., 2012). Descriptions of the phylogenetic and metabolic composition of microbial communities from other Juan de Fuca Ridge sediment environments are important for comprehensively investigating patterns in microbial distribution and community evolution with respect to gradients in the physical and chemical properties of the system.

During IODP Expedition 327, five boreholes were cored at Site U1363 (Fig. F1) (see the "Expedition 327 summary" chapter [Expedition 327 Scientists, 2011a]) adjacent to an exposed rocky seamount, Grizzly Bare outcrop (Fig. F2) (see the "Site U1363" chapter [Expedition 327 Scientists, 2011c]). Grizzly Bare serves as a point of seawater recharge into the igneous basement that is superimposed over basal basement fluid flow likely originating predominantly from the unsedimented ridge flanks. Sediment in this area is composed of turbidites inter- spersed with hemipelagic clay, consistent with core recovery from ODP and IODP boreholes at Sites 1026 and U1301 located $>50 \mathrm{~km}$ to the north-northeast (see the "Site U1363" chapter [Expedition 327 Scientists, 2011c]). Three sample types were collected from Holes U1363B and U1363G for the purpose of investigating microbial community structure:

1. Raw uncompressed sediment samples,

2. Squeezed sediment (i.e., squeeze cakes), and

3. Interstitial water derived from the squeeze cakes.

It is possible that the three sample types differ with respect to their resident microbial community structure based on strength of attachment of individual microbial lineages to sediment substrate. For example, squeeze cakes may represent communities that might be more tightly attached to the sediment, whereas interstitial water derived from the squeeze cakes may reflect a more loosely associated microbial community. In this investigation, the variety of samples from Holes U1363B and U1363G (Fig. F2) (see the "Site U1363" chapter [Expedition 327 Scientists, 2011c]) were investigated using SSU rRNA gene cloning and sequencing.

\section{Methods and materials}

\section{Sample collection and processing}

Samples were cored and collected from Holes U1363B and U1363G as described previously (see the "Methods" chapter [Expedition 327 Scientists, 2011b]); the subset of samples analyzed in this study is summarized in Table T1. Within the sample name, $\mathrm{H}$ and $\mathrm{X}$ indicate the two different coring methods that were employed: advanced piston corer or extended core barrel, respectively. For processing raw sediment samples, a sterile scoopula was used to transfer up to $20 \mathrm{~cm}^{3}$ of raw sediment into a $50 \mathrm{~mL}$ Falcon tube. DNA lysis buffer $(20 \mathrm{mM}$ tris$\mathrm{HCl}, 2 \mathrm{mM}$ EDTA, $1.2 \%$ Triton X-100, and 2\% lysozyme (w/v); $\mathrm{pH} 8)$ was added to just cover all of the sample material (10-20 $\mathrm{mL}$ ) and subsequently stored at $-80^{\circ} \mathrm{C}$ until further processing. In order to sample sediment interstitial water, sediment cores were pressed with $11 \mu \mathrm{m}$ pore-size grade Number 1 Whatman filter paper (Whatman, Maidstone, United Kingdom) in order to collect $\sim 10 \mathrm{~mL}$ of fluid that was subsequently filtered through a $0.1 \mu \mathrm{m}$ pore-size Supor membrane filter (Pall Corporation, Port Washington, NY, USA) by a sterile $20 \mathrm{~mL}$ syringe. Sterile forceps were used to transfer the membrane to a microcentrifuge tube, enough DNA lysis buffer was added to cover the membrane ( 2 mL), and the sample was stored at $-80^{\circ} \mathrm{C}$ until further 
processing. The pressed sediment cores, referred hereafter as squeeze cake samples, were preserved without addition of any buffers or reagents, wrapped in foil, and stored at $-80^{\circ} \mathrm{C}$ until further processing.

\section{DNA extraction}

All samples were thawed to room temperature and environmental DNA was extracted using the PowerMax Soil DNA isolation kit (MO BIO Laboratories, Carlsbad, CA, USA) following the manufacturer's protocol, with the following modifications (Mason et al., 2010):

1. After the addition of solution $\mathrm{C} 1$, two $5 \mathrm{~min}$ incubations at $65^{\circ} \mathrm{C}$ were performed with intermittent vortexing.

2. Bead beating was performed in $50 \mathrm{~mL}$ Falcon tubes using a Vortex Genie 2 benchtop vortexer (Scientific Industries, Bohemia, NY, USA) and a custom-made adapter for $1 \mathrm{~h}$ at maximum speed.

3. Nucleic acids were eluted using ultrapure water.

Bead beating for a lesser time was not attempted, and therefore some DNA shearing may have occurred. Up to $10 \mathrm{~g}$ of sediment and squeeze cake sample were used for nucleic acid extraction. For the interstitial water sample, the entire filter and associated lysis buffer were added to the bead beating tube and processed identically to other samples. Negative DNA extractions consisting of only kit reagents were processed in parallel to sediment and interstitial water sample extractions.

Nucleic acids were concentrated as outlined in the PowerMax Soil DNA isolation kit manual. Sodium chloride was added to the eluted nucleic acid extracts to a final concentration of $0.2 \mathrm{M}$ and mixed, followed by the addition of $100 \%$ ethanol at a ratio of $2: 1$ and further mixing. The mixture was centrifuged at $2500 \times \mathrm{g}$ for $30 \mathrm{~min}$ at room temperature. The supernatant was decanted, and the resulting pellet was washed with 70\% cold ethanol before evaporation overnight in a sterile laminar flow hood. Following evaporation, nucleic acid pellets were dissolved in ultrapure water and quantified by Picogreen fluorometric assay (Quant-iT dsDNA kit, Invitrogen, Carlsbad, CA, USA).

\section{SSU rRNA gene cloning and sequencing}

Small subunit rRNA gene fragments were amplified by polymerase chain reaction (PCR) using universal oligonucleotide primers 519F (5'-CAGCMGCCGCGGTAATWC-3') and 1406R (5'-ACGGGCGGTGTGTRC-3') (Lane et al., 1985). Each $20 \mu \mathrm{L}$ PCR reaction contained $0.5 \mathrm{U}$ of SpeedSTAR HS DNA polymerase
(Takara Bio, Inc., Otsu, Shiga, Japan), $1 \times$ fast buffer I, $200 \mu \mathrm{M}$ of each of the four deoxynucleoside triphosphate (dNTPs), $200 \mathrm{nM}$ of both forward and reverse primer, and $\sim 0.5-4 \mathrm{ng}$ of environmental DNA template. PCR cycling conditions consisted of an initial denaturation step at $95^{\circ} \mathrm{C}$ for $4 \mathrm{~min}$ followed by 25 cycles (Samples 1363B8X1_SC, 1363G1H2_SC, 1363G3H1_SC) or 34 cycles (Samples 1363B1H1_SC, 1363B1H1_RS, 1363B7X2_IW, extraction control) of $95^{\circ} \mathrm{C}$ denaturation for $30 \mathrm{~s}, 55^{\circ} \mathrm{C}$ annealing for 1 min, $72^{\circ} \mathrm{C}$ extension for $2 \mathrm{~min}$, and a final extension step at $72^{\circ} \mathrm{C}$ for $20 \mathrm{~min}$. Amplification products of the anticipated length were excised from an agarose gel and subsequently purified using the QIAquick gel extraction kit (Qiagen, Valencia, CA, USA). Products were cloned using the TOPO TA cloning kit (Invitrogen) following the manufacturer's instructions. Clones were sequenced unidirectionally with primer T7 on an ABI 3730XL DNA analyzer (Applied Biosystems, Carlsbad, CA, USA).

\section{Phylogenetic analysis}

DNA sequences were trimmed of vector sequence and manually curated using Sequencher version 5.1 (GeneCodes, Ann Arbor, MI, USA). Curated clone sequences were first aligned using the online SINA tool version 1.2.11 (Pruesse et al., 2012) before importing into the ARB software package (Ludwig et al., 2004; Westram et al., 2011) for manual curation of the multiple species alignment and taxonomic classification using version SSURef_111 of the SILVA ARB database (Pruesse et al., 2007; Prüsse et al., 2011). Clone sequences released to GenBank after the release of ARB database SSURef_111 that were highly related to clone sequences obtained in this study were downloaded and included in the relevant phylogenetic analyses. Maximum likelihood phylogenetic analyses were performed by RAxML using the GTR model of nucleotide substitution under the gamma model of rate heterogeneity (Stamatakis, 2006). Bootstrap analyses for phylogenetic trees containing large (>100 sequences; Chloroflexi and MCG) were determined by RAxML using 1000 bootstrap iterations by the CIPRES Science Gateway version 3.3 (Miller et al., 2010). All other bootstrap analyses were determined by RAxML using the rapid bootstrap analysis algorithm (1000 bootstraps) implemented within ARB (Stamatakis et al., 2008). All sequences generated in this study have been deposited in GenBank under accession numbers KC990940-KC991019.

\section{Microbial community analysis}

Microbial community analyses were performed using sequences containing $>700$ unambiguously 
aligned nucleotides (132 of 140 sequences). The UniFrac significance test (Lozupone et al., 2005) was used to evaluate whether the microbial community structure was different between sets of samples. A maximum likelihood-based phylogenetic tree containing all environmental sequences derived in this study was evaluated using an online implementation of the hypothesis testing approach (Lozupone et al., 2006). Significant differences in community structure within pairs of samples were evaluated using 100 permutations of both the weighted and unweighted implementations of the UniFrac algorithm. Bonferroni-corrected p-values are reported. Microbial community $\alpha$-diversity estimators, rarefaction curves, and community relatedness were generated or assessed using lane-masked clone sequences grouped into operational taxonomic units (OTUs) defined at 99\% and 97\% SSU rRNA gene sequence similarity cut-off values using the average neighbor clustering method as implemented by the mothur software package (Schloss et al., 2009). Microbial richness, evenness, and diversity were assessed by the Chao1 richness estimator $\left(\mathrm{S}_{\text {chaol }}\right.$; Chao, 1984), Simpson evenness index ( $\mathrm{E}_{\text {simpson; }}$ Simpson, 1949), and the nonparametric Shannon diversity index $\left(\hat{\mathrm{H}}_{\text {shannon; }}\right.$ Shannon, 1948), respectively, as implemented in mothur (Schloss et al., 2009).

\section{Results}

Universal oligonucleotide primers were used to PCR amplify, clone, and sequence SSU rRNA genes from Grizzly Bare sediment samples collected from Holes U1363B and U1363G in August to September 2010. A total of 118 environmental gene clones were sequenced (Table T2):

- 22 from Sample 327-U1363B-1H-1, 0-10 cm, squeeze cake (1363B1H1_SC);

- 19 from Sample 327-U1363B-1H-1, 130-140 cm, raw sediment (1363B1H1_RS);

- 23 from Sample 327-U1363B-7X-2, 125-145 $\mathrm{cm}$, interstitial water (1363B7X2_IW);

- 19 from Sample 327-U1363B-8X-1, 130-150 $\mathrm{cm}$, squeeze cake (1363B8X1_SC);

- 17 from Sample 327-U1363G-1H-2, 126-136 $\mathrm{cm}$, squeeze cake (1363G1H2_SC); and

- 18 from Sample 327-U1363G-3H-1, 140-150 cm, squeeze cake (1363G3H1_SC).

In addition, 22 clones were sequenced from the extraction control. The resulting microbial communities were analyzed using a variety of $\alpha$-diversity calculators and operational taxonomic units defined at 99\% and 97\% SSU rRNA gene sequence similarity (Table T3). The Shannon diversity index and Chao1 community diversity estimator indicated that Samples 1363B1H1_SC and 1363B8X1_SC had relatively high microbial diversity. The interstitial water sample had the lowest diversity found within all environmental samples, which may be expected because of the low sample size and therefore the amount of biomass likely contained within the interstitial water sample. Microbial diversity was highest in raw and pressed sediment, likely resulting from the larger amount of starting material used for nucleic acid extraction. The lowest diversity was found within the extraction control. The Simpson's evenness index revealed that squeeze cake samples had low community evenness. Microbial communities within the interstitial water sample were more even, due in part to putative microbial contamination, as explained below. Rarefaction curves generated using the same operational taxonomic unit definitions were for the most part steeply sloping, indicating that the clone libraries were undersampled (Fig. F3).

Both weighted and unweighted implementations of the UniFrac distance metric were used to perform microbial community structure comparisons among samples grouped by borehole location (i.e., all Hole U1363B samples versus all Hole U1363G samples) and borehole depth (i.e., surface core $[1 \mathrm{H}]$ versus deep cores [3H, 7X, and 8X]); comparisons were also performed using pairs of squeeze cake samples, a squeeze cake sample versus raw sediment sample from the same core section, and the interstitial water sample versus extraction control pair (Table T4). Significant differences in microbial community structure were observed between borehole locations when compared using the unweighted version of UniFrac. At both locations, surface samples had significantly different microbial community structure than their respective deep sediment samples. In pair-wise comparisons, individual squeeze cake sediment samples from both locations and at a range of depths did not significantly differ in microbial community structure by either the weighted or unweighted UniFrac measure). Similar comparisons revealed no significant differences between the squeeze cake sample and the raw sediment sample collected from the same core. Finally, microbial community structure in the sediment interstitial water sample was significantly different than the extraction control using the weighted version of UniFrac but not using the unweighted algorithm.

The surface sediment samples analyzed from Hole U1363B were collected from the 0.00-0.10 m (Sample 1363B1H1_SC) and 1.30-1.40 m (Sample 1363B1H1_RS) sections. Despite the small clone library size, five different phylogenetic groups were shared between the two samples (Table T2). Candi- 
date bacterial phylum BHI80-139 was the most abundant group detected in the Sample 1363B1H1_SC squeeze cake (5 of 22 clones), where it was most closely related to gene clones recovered from other samples described here and in marine sediment worldwide (e.g., Reed et al., 2002; Inagaki et al., 2006; Hoshino et al., 2011) (Fig. F4A). Candidate bacterial phylum JS1 formed the most abundant group detected in the surface raw sediment Sample 1363B1H1_RS (7 of 19 clones), where it was also most closely related to environmental gene clones recovered from other samples described here and in marine sediment worldwide (e.g., Li et al., 1999; Newberry et al., 2004; Briggs et al., 2011) (Fig. F4B). Uncultivated lineages within the bacterial phylum Chloroflexi were detected in surface sediment samples in relatively high abundance (Table T2); specifically, the vadinBA26 lineage was the most common group detected. Similar to the other groups mentioned above, highly related gene clones were detected in other samples described herein, as well as in marine sediment worldwide (e.g., Takeuchi et al., 2009; Durbin and Teske, 2011) (Fig. F5). Other less abundant clone groups recovered from Hole U1363B surface sediment include members of both the archaeal Miscellaneous Crenarchaeotal Group (MCG) and bacterial phyla Planctomycetes and Proteobacteria (Table T2; Fig. F6).

Sediment samples analyzed from Hole U1363B originated from deeper (and older) horizons that were 8$12 \mathrm{~m}$ above the sediment/basement interface and consisted of interstitial water collected from the 45.25-45.45 m section (Sample 1363B7X2_IW) and a sediment squeeze cake collected from the 48.80$49.00 \mathrm{~m}$ section (Sample 1363B8X1_SC). Candidate bacterial phylum BHI80-139 was the only group shared between the two samples (two clones from each library), where it formed two distinct lineages (Fig. F4A). The most abundant gene clone group identified from the interstitial water sample (11 of 23 clones) was highly related to the overwhelmingly dominant Firmicutes gene clone detected within the extraction control (21 of 22 clones), indicating that this group of sequences likely results from contamination; this is probably a reflection of the low amount of biomass obtained from this interstitial pore sample. Another abundant clone group from interstitial water (4 of 23 clones) was phylogenetically affiliated with the Salinimicrobium lineage of the phylum Bacteroidetes (Fig. F7A) and closely related to cultivated groups recovered from marine sediment (e.g., Ying et al., 2007) and terrestrial saline soil (e.g., Lim et al., 2008). These isolates are both aerobic and anaerobic heterotrophs. Another abundant group in interstitial water (4 of 23 clones) was phylogenetically related to the Trichocomaceae lineage of eukaryotic Fungi (Fig. F7B) and closely related to a fungus isolated from a saltern in China (GenBank acc. no. AY173080). The most abundant gene clone group identified from the deep squeeze cake sample from Hole U1363B (4 of 19 clones) was phylogenetically affiliated with archaeal lineage MCG-2, which is an uncultivated group of Archaea closely related to gene clones recovered from marine sediment (e.g., Colwell et al., 2005) (Fig. F6). Another abundant gene clone group recovered from the squeeze cake sample was related to the vadin 26 lineage of Chloroflexi described above (Fig. F5). Other less abundant clone groups recovered from Hole U1363B deep sediment include members of the bacterial phyla Chloroflexi and Planctomycetes, and candidate phyla BRC1, JS1, and OPB41 (Table T2; Figs. F4B, F5, F8A, F8B).

Squeeze cake sediment samples analyzed from Hole U1363G were collected from the 2.76-2.87 m section near the surface (Sample 1363G1H2_SC) and from a deeper horizon $\sim 10 \mathrm{~m}$ above the sediment/basement interface within the 17.40-17.50 m section (Sample 1363G3H1_SC). Similar to the samples described above, candidate bacterial phyla BHI80-139 and JS1 and lineages within the phylum Chloroflexi (i.e., Napoli-4B-65, Sh765B-AG-111, and vadinBA26) were shared between these samples, and all groups were phylogenetically related to gene clones that have previously been identified from marine sediment (e.g., Li et al., 1999; Reed et al., 2002; Newberry et al., 2004; Inagaki et al., 2006; Takeuchi et al., 2009; Briggs et al., 2011; Durbin and Teske, 2011; Hoshino et al., 2011). Candidate bacterial phylum JS1 formed the most abundant group detected ( 3 of 17 clones) in the near-surface squeeze cake sample from Hole U1363G (Fig. F4B), whereas the most abundant groups detected in the deeper squeeze cake sample were candidate bacterial phyla BHI80-139 and OPB41 (4 of 18 clones) (Table T2). Other less abundant clone groups recovered from Hole U1363G near-surface and deep sediment include members of both the MCG and bacterial phyla Chloroflexi, Planctomycetes, and Proteobacteria and candidate phylum TA06 (Figs. F5, F6, F8C).

OTUs generated using similarity cut-off values of 97\% and 99\% were used to generate gene clone clusters, which were used to also compare overlap between microbial communities (Figs. F9, F10, F11). Squeeze cakes and raw sediment shared an OTU cluster within the candidate phylum JS1 and multiple clusters within the candidate phylum BHI80-139 in most comparisons performed, indicating the potential widespread distribution of these groups within Grizzly Bare sediment. The single interstitial water 
sample from Hole U1363B shared one OTU cluster in common with the extraction control, which is related to the Tumebacillus lineage of Firmicutes. However, a majority of OTUs observed in the interstitial water sample were not found in the extraction control (Fig. F11C, F11D). In most comparisons, a majority of observed OTUs were unique to individual samples (Figs. F9, F10, F11).

A small subset of the gene clones identified in the samples characterized here have also been recovered from ridge flank fluids (Cowen et al., 2003; Huber et al., 2006b; Jungbluth et al., 2013). Environmental gene clones phylogenetically related to the vadinBA26 lineage of Chloroflexi and candidate bacterial phyla BHI80-139, OPB41, and TA06 have previously been detected from Baby Bare fluid samples (Huber et al., 2006b) (Figs. F4A, F5, F8B, F8C). In addition, lineage MCG-1 contained gene clones phylogenetically related to clones detected at Baby Bare Seamount, whereas lineages MCG-3 and MCG-8 contained clones phylogenetically related to others recovered from Hole U1301A ridge flank fluid (Jungbluth et al., 2013) and Baby Bare Seamount fluid (MCG-8; Huber et al., 2006b) (Fig. F6). Seven MCG lineages recovered from CORK-derived crustal fluid previously (Cowen et al., 2003; Huber et al., 2006b; Nakagawa et al., 2006; Orcutt et al., 2011b; Jungbluth et al., 2013) were not recovered from Grizzly Bare sediment in this study. Notably absent was the abundant MCG-12 (also known as lineage 1026B52) group detected in Hole 1026B (Cowen et al., 2003) and Hole U1301A fluid (Jungbluth et al., 2013) and rock chips (Orcutt et al., 2011b) (Fig. F6).

\section{Acknowledgments}

We thank the captain and crew of the R/V JOIDES Resolution and the Expedition 327 Shipboard Scientific Party. We also thank Karen Lloyd for providing a copy of her MCG ARB database, Jennifer Biddle and Amanda Martino for their thoughtful reviews, and Beth Orcutt and Geoff Wheat for useful discussion. This research was supported by funding from a Schlanger Ocean Drilling Fellowship to S.P. Jungbluth and an Expedition 327 participation grant (T327A4) to J.P. Cowen, both of which are part of the National Science Foundation (NSF)-sponsored United States Science Support Program for IODP administered by the Consortium for Ocean Leadership, a Center for Dark Energy Biosphere Investigations (C-DEBI; NSF award number 093956-4) Graduate Fellowship to S.P. Jungbluth and research award to M.S. Rappé, and the Center for Microbial Oceanography: Research and Education (C-MORE; award number EF0424599). This study used samples and/or data provided by the
Integrated Ocean Drilling Program (IODP). This is SOEST contribution 9024, HIMB contribution 1571, and Center for Dark Energy Biosphere Investigations (C-DEBI) contribution 181.

\section{References}

Alain, K., Olagnon, M., Desbruyères, D., Pagé, A., Barbier, G., Juniper, S.K., Quérellou, J., and Cambon-Bonavita, M.-A., 2002. Phylogenetic characterization of the bacterial assemblage associated with mucous secretions of the hydrothermal vent polychaete Paralvinella palmiformis. FEMS Microbiol. Ecol., 42(3):463-476. doi:10.1111/ j.1574-6941.2002.tb01035.x

Anderson, R.E., Beltrán, M.T., Hallam, S.J., and Baross, J.A., 2013. Microbial community structure across fluid gradients in the Juan de Fuca Ridge hydrothermal system. FEMS Microbiol. Ecol., 83(2):324-339. doi:10.1111/ j.1574-6941.2012.01478.x

Bidle, K.A., Kastner, M., and Bartlett, D.H., 1999. A phylogenetic analysis of microbial communities associated with methane hydrate containing marine fluids and sediments in the Cascadia margin (ODP Site 892B). FEMS Microbiol. Lett., 177(1):101-108. doi:10.1111/ j.1574-6968.1999.tb13719.x

Briggs, B.R., Inagaki, F., Morono, Y., Futagami, T., Huguet, C., Rosell-Mele, A., Lorenson, T.D., and Colwell, F.S., 2012. Bacterial dominance in subseafloor sediments characterized by methane hydrates. FEMS Microbiol. Ecol., 81(1):88-98. doi:10.1111/j.15746941.2012.01311.x

Briggs, B.R., Pohlman, J.W., Torres, M., Riedel, M., Brodie, E.L., and Colwell, F.S., 2011. Macroscopic biofilms in fracture-dominated sediment that anaerobically oxidize methane. Appl. Environ. Microbiol., 77(19):67806787. doi:10.1128/AEM.00288-11

Chao, A., 1984. Nonparametric estimation of the number of classes in a population. Scand. J. Stat., 11:265-270.

Colwell, F., Nunoura, T., Delwiche, M., Boyd, S., Bolton, R., Reed, D., Takai, K., Lehman, M., Horikoshi, K., and Phelps, T., 2005. Evidence of minimal methanogenic numbers and activity in sediments collected from the JAPEX/JNOC/JSC et al. Mallik 5L-38 gas hydrate production research well. In Dallimore, S.R., and Collett, T.S. (Eds.), Scientific Results from the Mallik 2002 Gas Hydrate Production Research Well Program, Mackenzie Delta, Northwest Territories, Canada. Bull.-Geol. Surv. Can., 585:111.

Cowen, J.P., Giovannoni, S.J., Kenig, F., Johnson, H.P., Butterfield, D., Rappé, M.S., Hutnak, M., and Lam, P., 2003. Fluids from aging ocean crust that support microbial life. Science, 299(5603):120-123. doi:10.1126/science. 1075653

Cragg, B.A., Summit, M., and Parkes, R.J., 2000. Bacterial profiles in a sulfide mound (Site 1035) and an area of active fluid venting (Site 1036) in hot hydrothermal sediments from Middle Valley (northwest Pacific). In Zierenberg, R.A., Fouquet, Y., Miller, D.J., and Normark, W.R. (Eds.), Proc. ODP, Sci. Results, 169: College Station, 
TX (Ocean Drilling Program), 1-18. doi:10.2973/ odp.proc.sr.169.105.2000

Davis, R.E., Stakes, D.S., Wheat, C.G., and Moyer, C.L., 2009. Bacterial variability within an iron-silica-manganese-rich hydrothermal mound located off-axis at the Cleft Segment, Juan de Fuca Ridge. Geomicrobiol. J., 26(8):570-580. doi:10.1080/01490450902889080

Durbin, A.M., and Teske, A., 2011. Microbial diversity and stratification of South Pacific abyssal marine sediments. Environ. Microbiol., 13(12):3219-3234. doi:10.1111/ j.1462-2920.2011.02544.X

Engelen, B., Ziegelmüller, K., Wolf, L., Köpke, B., Gittel, A., Cypionka, H., Treude, T., Nakagawa, S., Inagaki, F., Lever, M.A., and Steinsbu, B.O., 2008. Fluids from the ocean crust support microbial activities within the deep biosphere. Geomicrobiol. J., 25(1):56-66. doi:10.1080/ 01490450701829006

Expedition 301 Scientists, 2005. Expedition 301 summary. In Fisher, A.T., Urabe, T., Klaus, A., and the Expedition 301 Scientists, Proc. IODP, 301: College Station, TX (Integrated Ocean Drilling Program Management International, Inc.). doi:10.2204/iodp.proc.301.101.2005

Expedition 327 Scientists, 2011a. Expedition 327 summary. In Fisher, A.T., Tsuji, T., Petronotis, K., and the Expedition 327 Scientists, Proc. IODP, 327: Tokyo (Integrated Ocean Drilling Program Management International, Inc.). doi:10.2204/iodp.proc.327.101.2011

Expedition 327 Scientists, 2011b. Methods. In Fisher, A.T., Tsuji, T., Petronotis, K., and the Expedition 327 Scientists, Proc. IODP, 327: Tokyo (Integrated Ocean Drilling Program Management International, Inc.). doi:10.2204/iodp.proc.327.102.2011

Expedition 327 Scientists, 2011c. Site U1363. In Fisher, A.T., Tsuji, T., Petronotis, K., and the Expedition 327 Scientists, Proc. IODP, 327: Tokyo (Integrated Ocean Drilling Program Management International, Inc.). doi:10.2204/iodp.proc.327.106.2011

Hoshino, T., Morono, Y., Terada, T., Imachi, H., Ferdelman, T.G., and Inagaki, F., 2011. Comparative study of subseafloor microbial community structures in deeply buried coral fossils and sediment matrices from the Challenger Mound in the Porcupine Seabight. Front. Extreme Microbiol., 2:231. doi:10.3389/ fmicb.2011.00231

Huber, J.A., Butterfield, D.A., and Baross, J.A., $2006 a$. Diversity and distribution of subseafloor Thermococcales populations in diffuse hydrothermal vents at an active deep-sea volcano in the northeast Pacific Ocean. J. Geophy. Res.: Biogeosciences, 111(G4):G04016. doi:10.1029/2005JG000097

Huber, J.A., Johnson, H.P., Butterfield, D.A., and Baross, J.A., 2006b. Microbial life in ridge flank crustal fluids. Environ. Microbiol., 88(1):88-99. doi:10.1111/j.14622920.2005.00872.x

Huber, J.A., Morrison, H.G., Huse, S.M., Neal, P.R., Sogin, M.L., and Welch, D.B.M., 2009. Effect of PCR amplicon size on assessments of clone library microbial diversity and community structure. Environ. Microbiol., 11(5):1292-1302. doi:10.1111/j.14622920.2008.01857.x
Hutnak, M., Fisher, A.T., Zühlsdorff, L., Spiess, V., Stauffer, P.H., and Gable, C.W., 2006. Hydrothermal recharge and discharge guided by basement outcrops on 0.7-3.6 Ma seafloor east of the Juan de Fuca Ridge: observations and numerical models. Geochem., Geophys., Geosyst., 7(7):Q07O02. doi:10.1029/2006GC001242

Inagaki, F., Nunoura, T., Nakagawa, S., Teske, A., Lever, M., Lauer, A., Suzuki, M., Takai, K., Delwiche, M., Colwell, F.S., Nealson, K.H., Horikoshi, K., D'Hondt, S., and Jørgensen, B.B., 2006. Biogeographical distribution and diversity of microbes in methane hydrate-bearing deep marine sediments on the Pacific Ocean margin. Proc. Natl. Acad. Sci. U. S. A., 103(8):2815-2820. doi:10.1073/ pnas.0511033103

Jungbluth, S.P., Grote, J., Lin, H.-T., Cowen, J.P., and Rappé, M.S., 2013. Microbial diversity within basement fluids of the sediment-buried Juan de Fuca Ridge flank. ISME J., 7:161-172. doi:10.1038/ismej.2012.73

Kaye, J.Z., Sylvan, J.B., Edwards, K.J., and Baross, J.A., 2011. Halomonas and Marinobacter ecotypes from hydrothermal vent, subseafloor and deep-sea environments. FEMS Microbiol. Ecol., 75(1):123-133. doi:10.1111/j.15746941.2010.00984.X

Knittel, K., Boetius, A., Lemke, A., Eilers, H., Lochte, K., Pfannkuche, O., Linke, P., and Amann, R., 2003. Activity, distribution, and diversity of sulfate reducers and other bacteria in sediments above gas hydrate (Cascadia margin, Oregon). Geomicrobiol. J., 20(4):269-294. doi:10.1080/01490450303896

Kubo, K., Lloyd, K.G., Biddle, J.F., Amann, R., Teske, A., and Knittel, K., 2012. Archaea of the Miscellaneous Crenarchaeotal Group are abundant, diverse and widespread in marine sediments. ISME J., 6(10):1949-1965. doi:10.1038/ismej.2012.37

Lane, D.J., Pace, B., Olsen, G.J., Stahl, D.A., Sogin, M.L., and Pace, N.R., 1985. Rapid determination of 16 S ribosomal RNA sequences for phylogenetic analyses. Proc. Natl. Acad. Sci. U. S. A., 82(20):6955-6959. doi:10.1073/ pnas.82.20.6955

Lever, M.A., Rouxel, O., Alt, J.C., Shimizu, N., Ono, S., Coggon, R.M., Shanks, W.C., III, Laphan, L., Elvert, M., Prieto-Mollar, X., Hinrichs, K.-U., Inagaki, F., and Teske, A., 2013. Evidence for microbial carbon and sulfur cycling in deeply buried ridge flank basalt. Science, 339(6125):1305-1308. doi:10.1126/science.1229240

Li, L., Kato, C., and Horikoshi, K., 1999. Microbial diversity in sediments collected from the deepest cold-seep area, the Japan Trench. Mar. Biotechnol., 1(4):391-400. doi:10.1007/PL00011793

Lim, J.-M., Jeon, C.O., Lee, S.S., Park, D.-J., Xu, L.-H., Jiang, C.-L., and Kim, C.-J., 2008. Reclassification of Salegentibacter catena Ying et al. 2007 as Salinimicrobium catena gen. nov., comb. nov. and description of Salinimicrobium xinjiangense sp. nov., a halophilic bacterium isolated from Xinjiang province in China. Int. J. Syst. Evol. Microbiol., 58(2):438-442. doi:10.1099/ijs.0.65297-0

Lozupone, C., Hamady, M., and Knight, R., 2006. UniFrac-an online tool for comparing microbial community diversity in a phylogenetic context. BMC Bioinf., 7(1):371. doi:10.1186/1471-2105-7-371 
Lozupone, C., and Knight, R., 2005. UniFrac: a new phylogenetic method for comparing microbial communities. Appl. Environ. Microbiol., 71(12):8228-8235. doi:10.1128/AEM.71.12.8228-8235.2005

Ludwig, W., Strunk, O., Westram, R., Richter, L., Meier, H., Kumar, Y., Buchner, A., Lai, T., Steppi, S., Jobb, G., Förster, W., Brettske, I., Gerber, S., Ginhart, A.W., Gross, O., Grumann, S., Hermann, S., Jost, R., König, A., Liss, T., Lüßmann, R., May, M., Nonhoff, B., Reichel, B., Strehlow, R., Stamatakis, A., Stuckmann, N., Vilbig, A., Lenke, M., Ludwig, T., Bode, A., and Schleifer, K.-H., 2004. ARB: a software environment for sequence data. Nucleic Acids Res., 32(4):1363-1371. doi:10.1093/nar/ gkh293

Lynch, K.S., 2000. Bacterial community structure and phylogenetic diversity of hydrothermal vents at Axial Volcano, Juan de Fuca Ridge [M.S. thesis]. Western Washington Univ., Bellingham.

Marchesi, J.R., Weightman, A.J., Cragg, B.A., Parkes, R.J., and Fry, J.C., 2001. Methanogen and bacterial diversity and distribution in deep gas hydrate sediments from the Cascadia margin as revealed by $16 \mathrm{~S}$ rRNA molecular analysis. FEMS Microbiol. Ecol., 34(3):221-228. doi:10.1111/j.1574-6941.2001.tb00773.x

Mason O.U., Di Meo-Savoie, C.A., Van Nostrand, J.D., Zhou, J., Fisk, M.R., and Giovannoni, S.J., 2009. Prokaryotic diversity, distribution, and insights into their role in biogeochemical cycling in marine basalts. ISME J., 3:231-242. doi:10.1038/ismej.2008.92

Mason, O.U., Nakagawa, T., Rosner, M., Van Nostrand, J.D., Zhou, J., Maruyama, A., Fisk, M.R., and Giovannoni, S.J., 2010. First investigation of the microbiology of the deepest layer of ocean crust. PLoS One, 5(11):e15399. doi:10.1371/journal.pone.0015399

Mason, O.U., Stingl, U., Wilhelm, L.J., Moeseneder, M.M., Di Meo-Savoie, C.A., Fisk, M.R., and Giovannoni, S.J., 2007. The phylogeny of endolithic microbes associated with marine basalts. Environ. Microbiol., 9(10):25392550. doi:10.1111/j.1462-2920.2007.01372.x

Mather, I.D., and Parkes, R.J., 2000. Bacterial profiles in sediments of the eastern flank of the Juan de Fuca Ridge, Sites 1026 and 1027. In Fisher, A., Davis, E.E., and Escutia, C. (Eds.), Proc. ODP, Sci. Results, 168: College Station, TX (Ocean Drilling Program), 161-165. doi:10.2973/odp.proc.sr.168.023.2000

Meyer, J.L., Akerman, N.H., Proskurowski, G., and Huber J.A., 2013. Microbiological characterization of posteruption "snowblower" vents at Axial Seamount, Juan de Fuca Ridge. Front. Microbiol., 4:153. doi:10.3389/ fmicb.2013.00153

Miller, M.A., Pfeiffer, W., and Schwartz, T., 2010. Creating the CIPRES science gateway for inference of large phylogenetic trees. GCE Workshop, 1-8. doi:10.1109/ GCE.2010.5676129

Nakagawa, S., Inagaki, F., Suzuki, Y., Steinsbu, B.O., Lever, M.A., Takai, K., Engelen, B., Sako, Y., Wheat, C.G., Horikoshi, K., and Integrated Ocean Drilling Program Expedition 301 Scientists, 2006. Microbial community in black rust exposed to hot ridge-flank crustal fluids. Appl.
Environ. Microbiol., 72(10):6789-6799. doi:10.1128/ AEM.01238-06

Newberry, C.J., Webster, G., Cragg, B.A., Parkes, R.J., Weightman, A.J., and Fry, J.C., 2004. Diversity of prokaryotes and methanogenesis in deep subsurface sediments from the Nankai Trough, Ocean Drilling Program Leg 190. Environ. Microbiol., 6(3):274-287. doi:10.1111/ j.1462-2920.2004.00568.x

Nunoura, T., Inagaki, F., Delwiche, M.E., Colwell, F.S., and Takai, K., 2008. Subseafloor microbial communities in methane hydrate-bearing sediment at two distinct locations (ODP Leg 204) in the Cascadia Margin. Microbes Environ., 23(4):317-325. doi:10.1264/jsme2.ME08514

Orcutt, B.N., Bach, W., Becker, K., Fisher, A.T., Hentscher, M., Toner, B.M., Wheat, C.G., and Edwards, K.J., 2011a. Colonization of subsurface microbial observatories deployed in young ocean crust. ISME J., 5(4):692-703. doi:10.1038/ismej.2010.157

Orcutt, B.N., Sylvan, J.B., Knab, N.J., and Edwards, K.J., 2011b. Microbial ecology of the dark ocean above, at, and below the seafloor. Microbiol. Mol. Biol. Rev., 75(2):361-422. doi:10.1128/MMBR.00039-10

Pagé, A., Juniper, S.K., Olagnon, M., Alain, K., Desrosiers, G., Quérellou, J., and Cambon-Bonavita, M.-A., 2004. Microbial diversity associated with a Paralvinella sulfincola tube and the adjacent substratum on an active deepsea vent chimney. Geobiology, 2(4):225-238. doi:10.1111/j.1472-4677.2004.00034.x

Pruesse, E., Peplies, J., and Glöckner, F.O., 2012. SINA: accurate high-throughput multiple sequence alignment of ribosomal RNA genes. Bioinformatics, 28(14):1823-1829. doi:10.1093/bioinformatics/ bts 252

Pruesse, E., Quast, C., Knittel, K., Fuchs, B.M., Ludwig, W., Peplies, J., and Glöckner, F.O., 2007. SILVA: a comprehensive online resource for quality checked and aligned ribosomal RNA sequence data compatible with ARB. Nucleic Acids Res., 35(21):7188-7196. doi:10.1093/nar/ gkm864

Prüsse, E., Quast, C., Yilmaz, P., Ludwig, W., Peplies, J., and Glöckner, F.O., 2011. SILVA: comprehensive databases for quality checked and aligned ribosomal RNA sequence data compatible with ARB. In de Bruijn, F.J. (Ed.), Handbook of Molecular Microbial Ecology I: Metagenomics and Complementary Approaches: Hoboken, NJ (Wiley-Blackwell), 393-398. doi:10.1002/ 9781118010518.ch45

Reed, D.W., Fujita, Y., Delwiche, M.E., Blackwelder, D.B., Sheridan, P.P., Uchida, T., and Colwell, F.S., 2002. Microbial communities from methane hydrate-bearing deepmarine sediments in a forearc basin. Appl. Environ. Microbiol., 68(8):3759-3770. doi:10.1128/ AEM.68.8.3759-3770.2002

Rosenberger, A., Davis, E.E., and Villinger, H., 2000. Data report: hydrocell-95 and -96 single-channel seismic data on the eastern Juan de Fuca Ridge Flank. In Fisher, A., Davis, E.E., and Escutia, C. (Eds.), Proc. ODP, Sci. Results, 168: College Station, TX (Ocean Drilling Program), 919. doi:10.2973/odp.proc.sr.168.021.2000 
Schloss, P.D., Westcott, S.L., Ryabin, T., Hall, J.R., Hartmann, M., Hollister, E.B., Lesniewski, R.A., Oakley, B.B., Parks, D.H., Robinson, C.J., Sahl, J.W., Stres, B., Thallinger, G.G., Van Horn, D.J., and Weber, C.F., 2009. Introducing mothur: open-source, platform-independent, community-supported software for describing and comparing microbial communities. Appl. Environ. Microbiol., 75(23):7537-7541. doi:10.1128/AEM.01541-09

Shannon, C.E., 1948. A mathematical theory of communication. Tech. J. Bell Lab., 27:379-423.

Shipboard Scientific Party, 1992. Introduction. In Davis, E.E., Mottl, M.J., Fisher, A.T., et al., Proc. ODP, Init. Repts., 139: College Station, TX (Ocean Drilling Program), 5-7. doi:10.2973/odp.proc.ir.139.101.1992

Shipboard Scientific Party, 1997. Introduction and summary: hydrothermal circulation in the oceanic crust and its consequences on the eastern flank of the Juan de Fuca Ridge. In Davis, E.E., Fisher, A.T., Firth, J.V., et al., Proc. ODP, Init. Repts., 168: College Station, TX (Ocean Drilling Program), 7-21. doi:10.2973/ odp.proc.ir.168.101.1997

Simpson, E.H., 1949. Measurement of diversity. Nature (London, U. K.), 163(4148):688. doi:10.1038/163688a0

Smith, A., Popa, R., Fisk, M., Nielsen, M., Wheat, C.G., Jannasch, H.W., Fisher, A.T., Becker, K., Sievert, S.M., and Flores, G., 2011. In situ enrichment of ocean crust microbes on igneous minerals and glasses using an osmotic flow-through device. Geochem., Geophys., Geosyst., 12(6):Q06007. doi:10.1029/2010GC003424

Stamatakis, A., 2006. RAxML-VI-HPC: maximum likelihood-based phylogenetic analyses with thousands of taxa and mixed models. Bioinformatics, 22(21):26882690. doi:10.1093/bioinformatics/btl446

Stamatakis, A., Hoover, P., and Rougemont, J., 2008. A rapid bootstrap algorithm for the RAxML web servers. Syst. Biol., 57(5):758-771. doi:10.1080/ 10635150802429642

Takeuchi, M., Komai, T., Hanada, S., Tamaki, H., Tanabe, S., Miyachi, Y., Uchiyama, M., Nakazawa, T., Kimura, K., and Kamagata, Y., 2009. Bacterial and archaeal 16S rRNA genes in late Pleistocene to Holocene muddy sediments from the Kanto Plain of Japan. Geomicrobiol. J., 26(2):104-118. doi:10.1080/01490450802662355

Wang, F., Zhou, H., Meng, J., Peng, X., Jiang, L., Sun, P., Zhang, C., Van Nostrand, J.D., Deng, Y., He, Z., Wu, L., Zhou, J., and Xiao, X., 2009a. GeoChip-based analysis of metabolic diversity of microbial communities at the Juan de Fuca Ridge hydrothermal vent. Proc. Natl. Acad. Sci. U. S. A., 106(12):4840-4845. doi:10.1073/ pnas.0810418106

Wang, S., Xiao, X., Jiang, L., Peng, X., Zhou, H., Meng, J., and Wang, F., 2009b. Diversity and abundance of ammonia-oxidizing archaea in hydrothermal vent chimneys of the Juan de Fuca Ridge. Appl. Environ. Microbiol., 75(12):4216-4220. doi:10.1128/AEM.0176108

Westram, R., Bader, K., Prüsse, E., Kumar, Y., Meier, H., Glöckner, F.O., and Ludwig, W., 2011. ARB: a software environment for sequence data. In de Bruijn, F.J. (Ed.), Handbook of Molecular Microbial Ecology I: Metagenomics and Complementary Approaches: Hoboken, NJ (WileyBlackwell), 399-406. doi:10.1002/

9781118010518.ch46

Wheat, C.G., Hulme, S.M., Fisher, A.T., Orcutt B.N., and Becker, K., 2013. Seawater recharge into oceanic crust: IODP Exp. 327 Site U1363 Grizzly Bare outcrop. Geochem., Geophys., Geosyst., 14(6):1957-1972. doi:10.1002/ggge.20131

Ying, J.-Y., Liu, Z.-P., Wang, B.-J., Dai, X., Yang, S.-S., and Liu, S.-J., 2007. Salegentibacter catena sp. nov., isolated from sediment of the South China Sea, and emended description of the genus Salegentibacter. Int. J. Syst. Evol. Microbiol., 57(2):219-222. doi:10.1099/ijs.0.64658-0

Zhou, H., Li, J., Peng, X., Meng, J., Wang, F., and Ai, Y., 2009. Microbial diversity of a sulfide black smoker in main endeavour hydrothermal vent field, Juan de Fuca Ridge. J. Microbiol., 47(3):235-247. doi:10.1007/ s12275-008-0311-z

Zühlsdorff, L., Hutnak, M., Fisher, A.T., Spiess, V., Davis, E.E., Nedimovic, M., Carbotte, S., Villinger, H., and Becker, K., 2005. Site surveys related to IODP Expedition 301: ImageFlux (SO149) and RetroFlux (TN116) expeditions and earlier studies. In Fisher, A.T., Urabe, T., Klaus, A., and the Expedition 301 Scientists, Proc. IODP, 301: College Station, TX (Integrated Ocean Drilling Program Management International, Inc.). doi:10.2204/ iodp.proc.301.102.2005

Initial receipt: 6 May 2013

Acceptance: 2 September 2013

Publication: 25 November 2013

MS 327-201 
Figure F1. A. Site locations, Integrated Ocean Drilling Program (IODP) Expedition 327. Site U1363 is adjacent to a large basement outcrop $\sim 52 \mathrm{~km}$ south-southwest of the dashed line that denotes Ocean Drilling Program (ODP) Leg 168 (Shipboard Scientific Party, 1997). The yellow box indicates the location of B (modified from Expedition 327 Scientists, 2011a). B. Regional bathymetry of Expedition 327 and previous expedition sites and basement outcrops. Thermal and chemical data suggest hydrothermal fluids recharge at Grizzly Bare outcrop and flow north-northeast (white arrow). The yellow box indicates the location of $C$ (modified from Expedition 327 Scientists, 2011a). C. Bathymetry around Grizzly Bare outcrop and Site U1363. Black lines indicate tracks of reflection seismic lines around Hole U1363B collected during the 2000 ImageFlux expedition (Zühlsdorff et al., 2005; Hutnak et al., 2006). Part of Line GeoB00-170 (red line) is shown in Figure F2A (modified from Expedition 327 Scientists, 2011c).
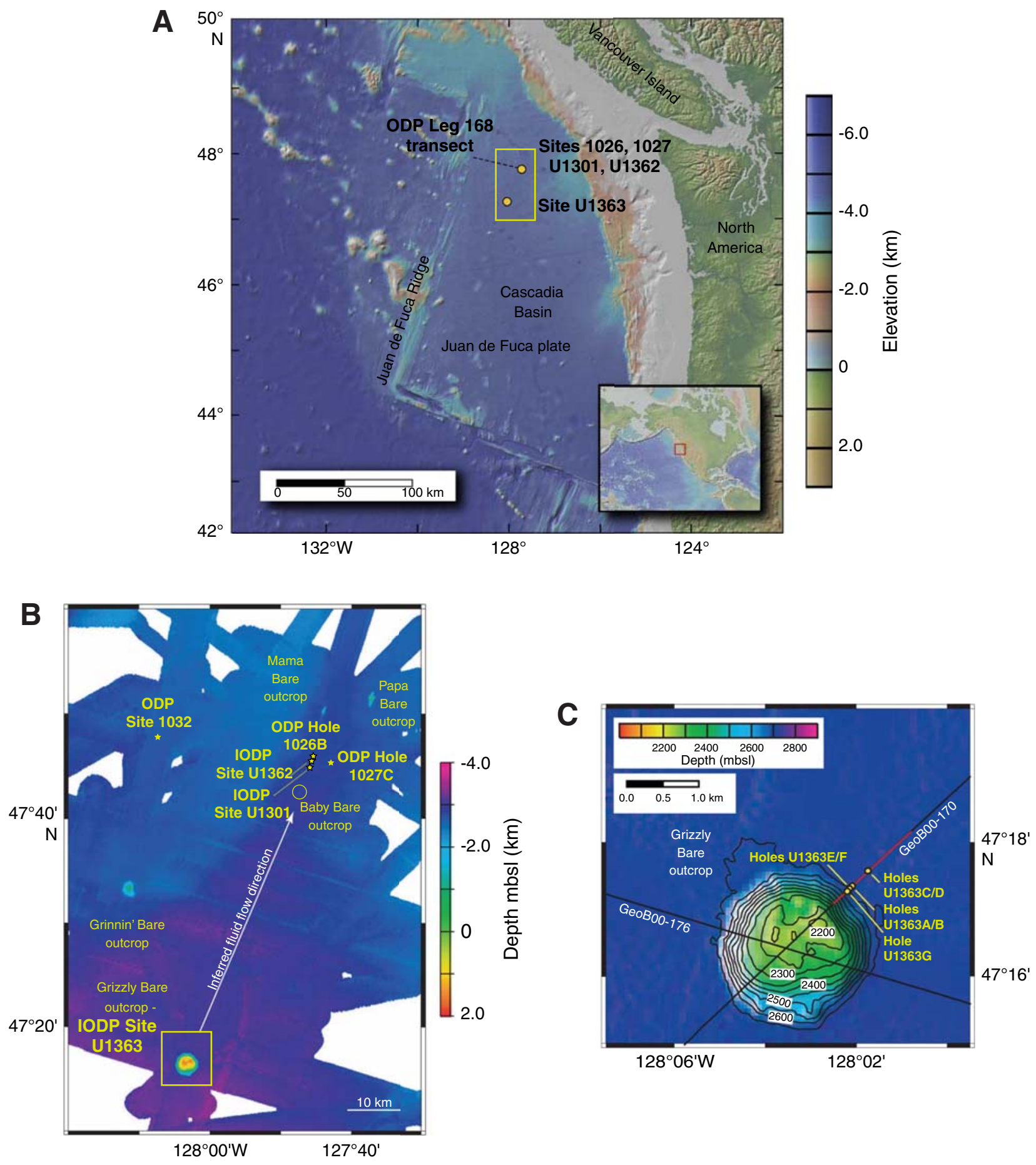
Figure F2. A. Three-dimensional perspective views of basement relief around Site U1363 adjacent to Grizzly Bare outcrop. Bathymetry based on digitization of seismic lines across work areas (data from Rosenberger et al., 2000; Zühlsdorff et al., 2005; Hutnak et al., 2006). Relief is shown as two-way traveltime, with no conversion to sediment thickness or depth. Part of Line GeoB00-170 (as shown in Figure F1C) is overlaid here to approximate sediment thickness (modified from Expedition 327 Scientists, 2011a). B. Seismic Line GeoB00-170 across Holes U1363A-U1363G. The sediment/basalt interface is clearly visible, but internal structure of the Grizzly Bare edifice is less resolved. Blue boxes indicate the locations of Holes U1363G and U1363B, which are shown in C (modified from Expedition 327 Scientists, 2011c). (Continued on next page.)

A

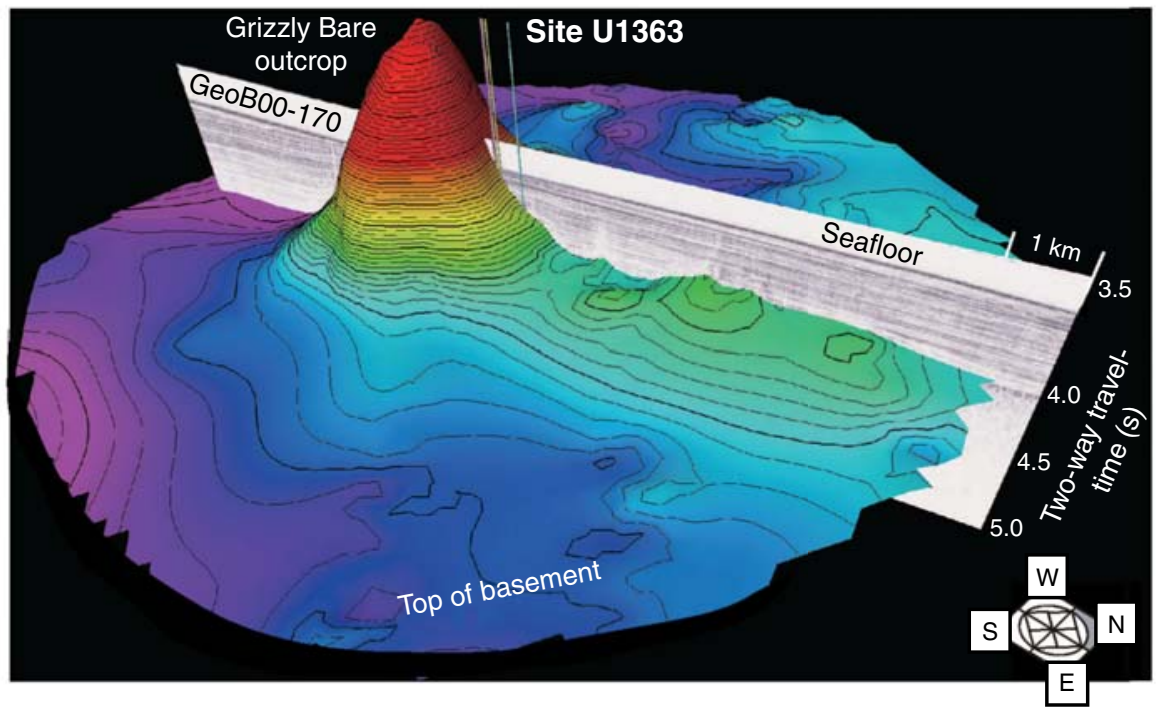

B

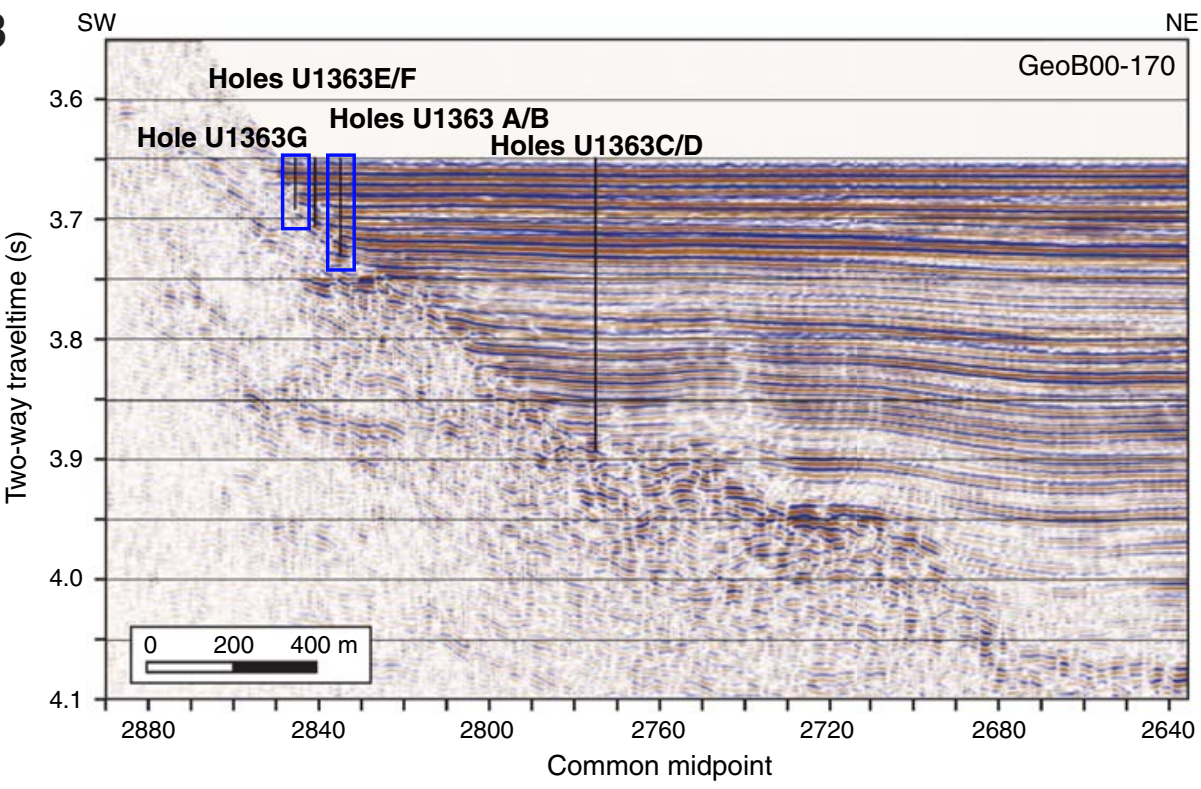


Figure F2 (continued). C. Lithostratigraphy of Holes U1363G (left) and U1363B (right). Core recovery: black $=$ recovered, white $=$ not recovered. Red lines indicate locations of samples within the sediment column (modified from Expedition 327 Scientists, 2011c).
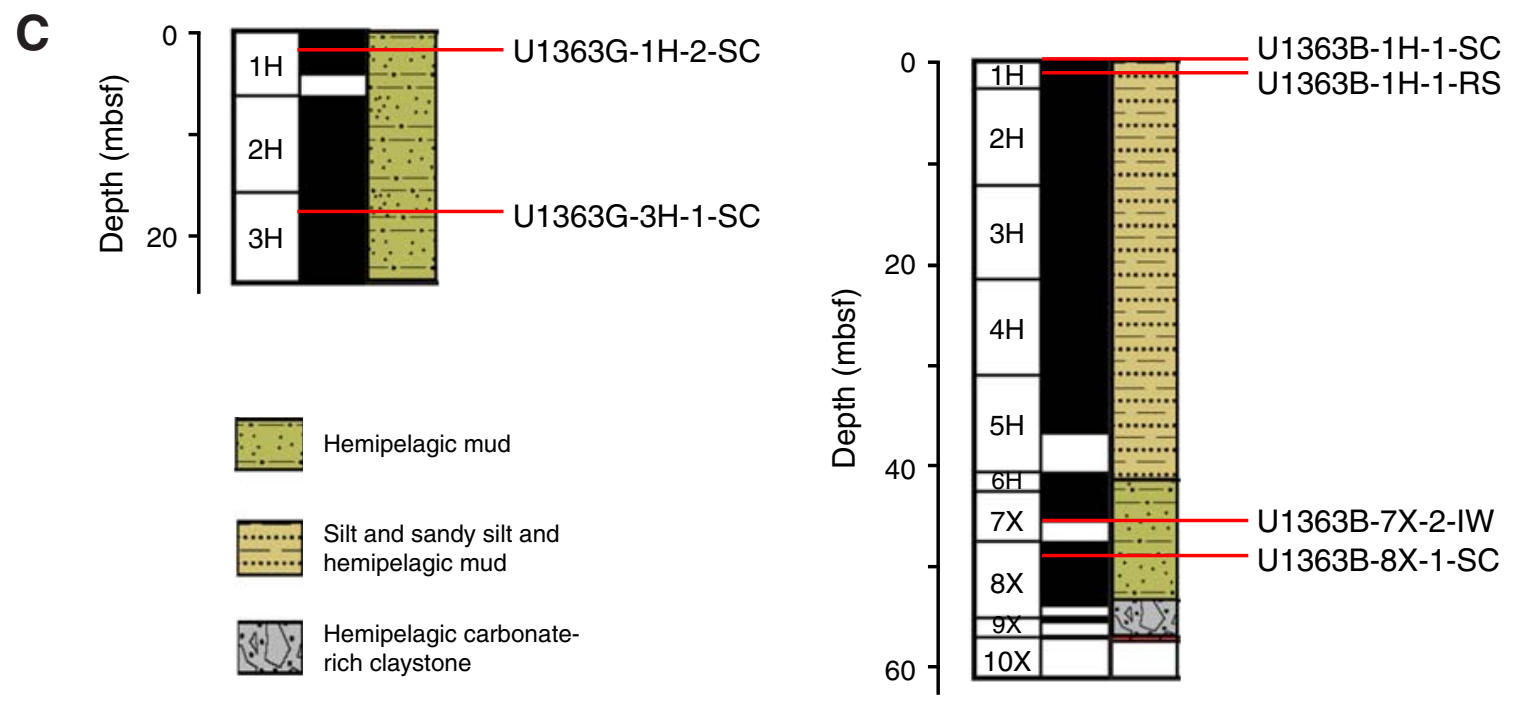
Figure F3. Rarefaction curves displaying the number of operational taxonomic units (OTUs) observed given the sequencing effort for Grizzly Bare sediment samples, Holes U1363B and U1363G. Data clustered at either $99 \%$ or $97 \%$ similarity cut-off values.

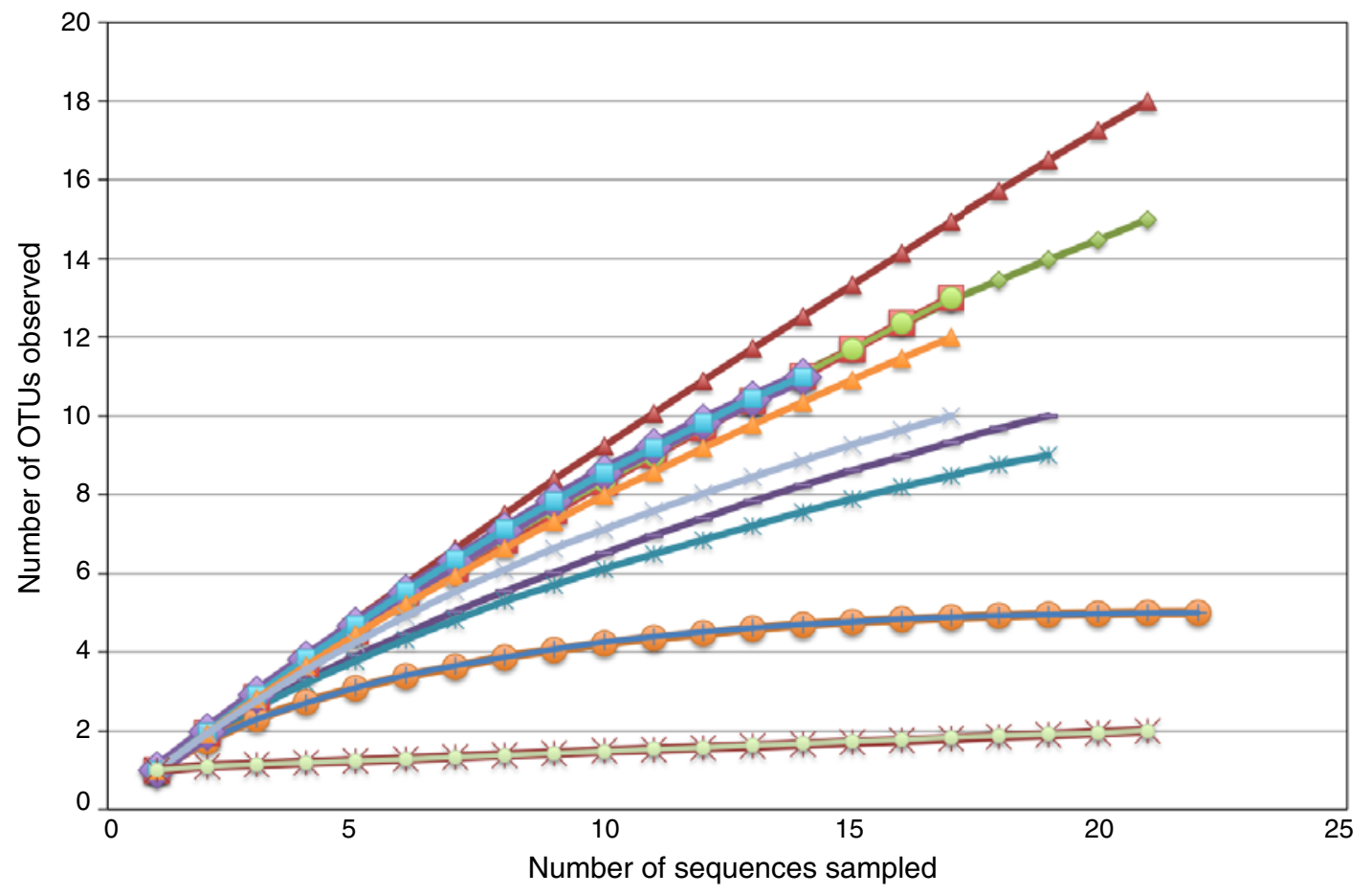

- U1363B-1H-1-SC (99\%)

$\approx$ U1363B-1H-1-SC (97\%)

U U1363B-1H-1-RS (99\%)

$m$ U1363B-1H-1-RS (97\%)

U1363B-7X-2-IW (99\%)

+ U1363B-7X-2-IW (97\%)

U1363B-8X-1-SC (99\%)

$\multimap$ U1363B-8X-1-SC (97\%)

$\Leftrightarrow$ U1363G-1H-2-SC (99\%)

$=$ U1363G-1H-2-SC (97\%)

$=$ U1363G-3H-1-SC (99\%)

$\oiiint$ U1363G-3H-1-SC (97\%)

Extraction control (99\%)

- Extraction control (97\%) 
Figure F4. Phylogenetic relationships of Grizzly Bare sediment gene clones related to (A) candidate bacterial phylum BHI80-139 and (B) candidate bacterial phylum JS1. Lineage in blue text was previously recovered from Juan de Fuca Ridge flank Baby Bare fluids (Huber et al., 2006b). Cultivated Dictyoglomaceae and Thermoanaerobacteraceae in A and cultivated Halanaerobiaceae in B were used as outgroups (not shown). Open circles indicate nodes with bootstrap support between $50 \%$ and $80 \%$, whereas solid circles indicate bootstrap support $>80 \%$, from 1000 replicates. Gene clones recovered in this study are highlighted in bold; the fractional abundance of identical clones recovered from the sample is listed in parentheses. Scale bars correspond to 0.1 substitutions per nucleotide position. (Continued on next page.)

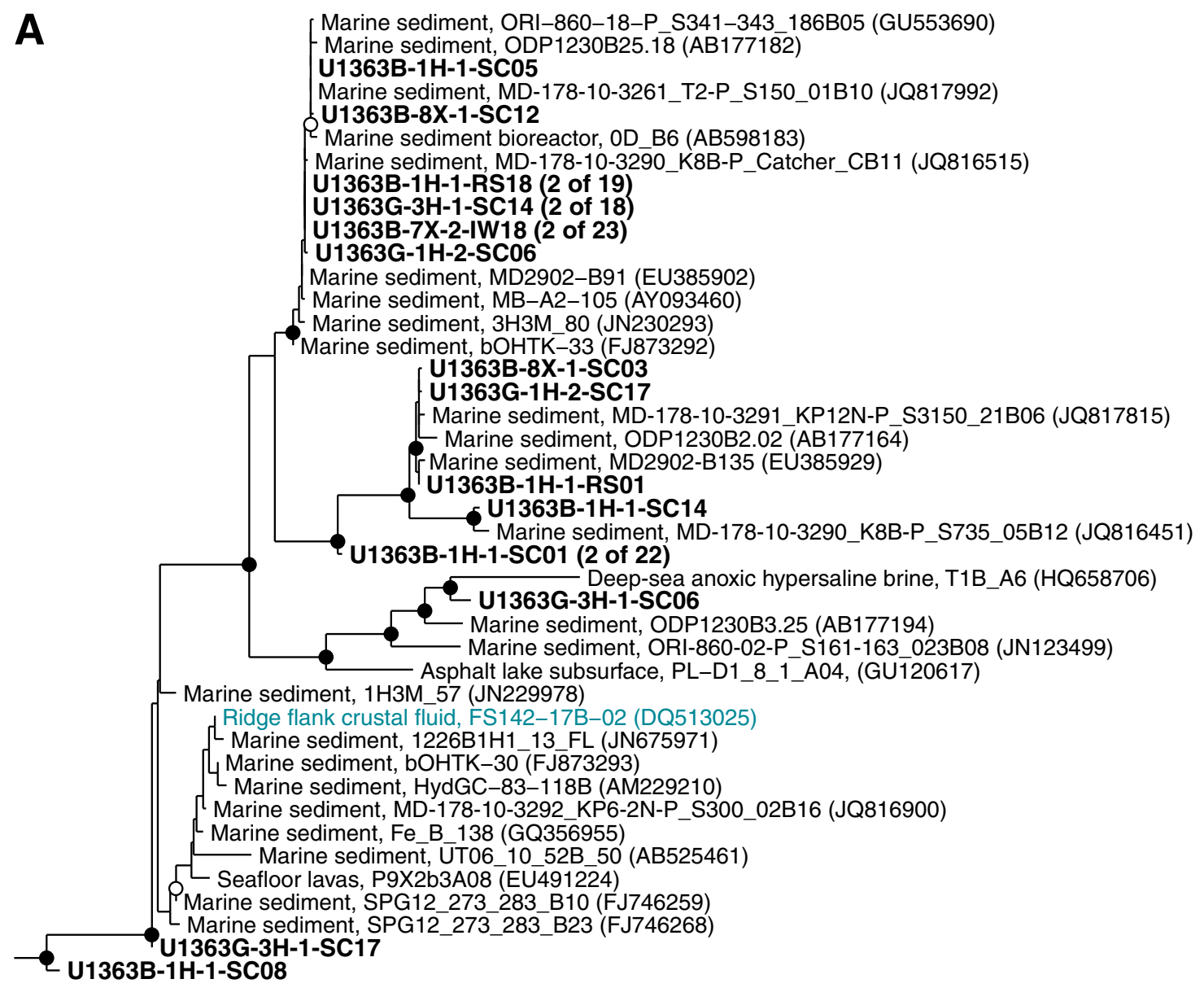


Figure F4 (continued).

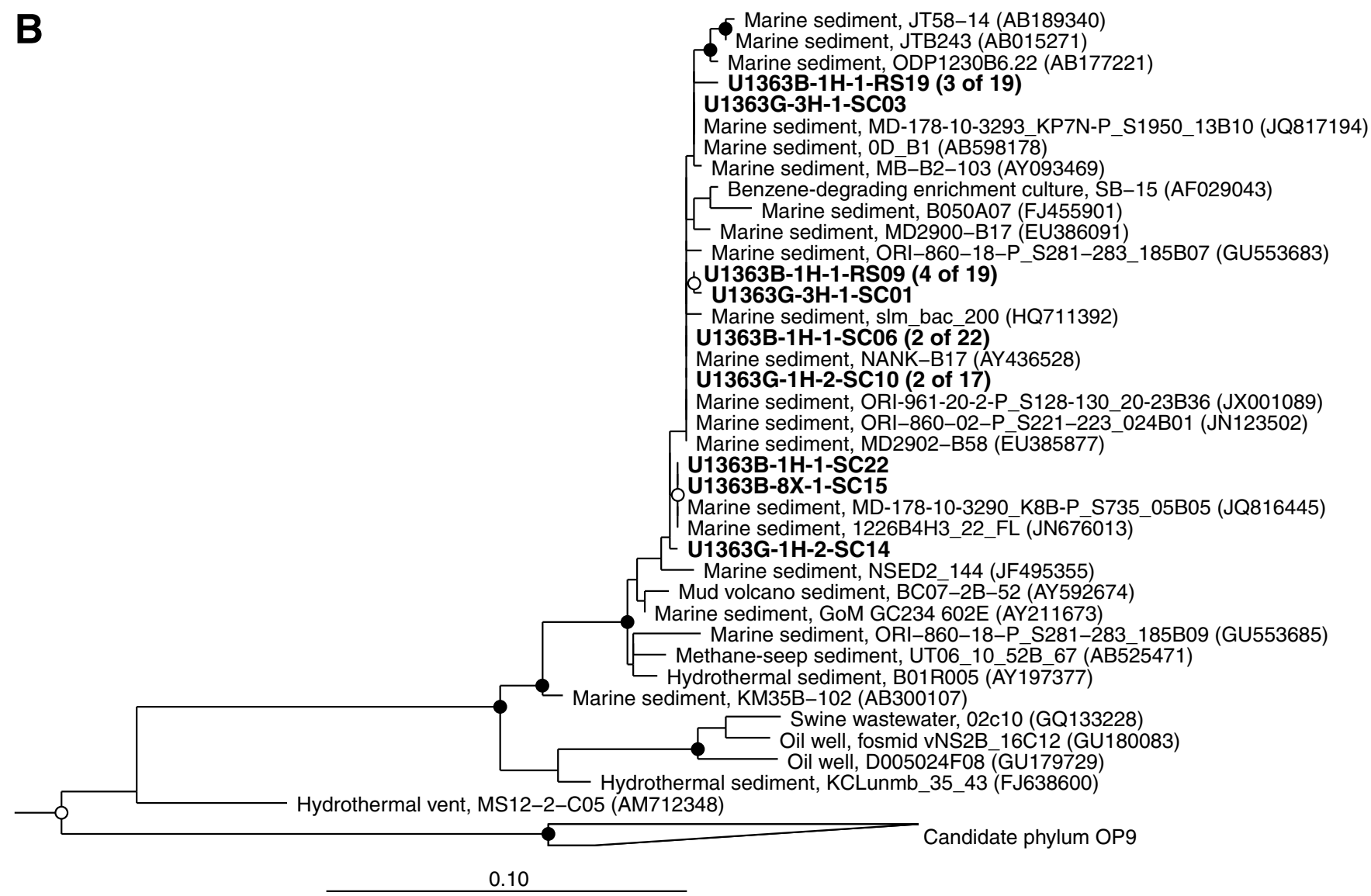


Figure F5. Phylogenetic relationships of Grizzly Bare sediment small subunit ribosomal RNA gene clones related to the bacterial phylum Chloroflexi. Lineage in blue text was previously recovered from Juan de Fuca Ridge flank Baby Bare fluids (Huber et al., 2006b). Cultivated Actinobacteria were used as an outgroup. See Figure F4 for symbol definitions and other information.

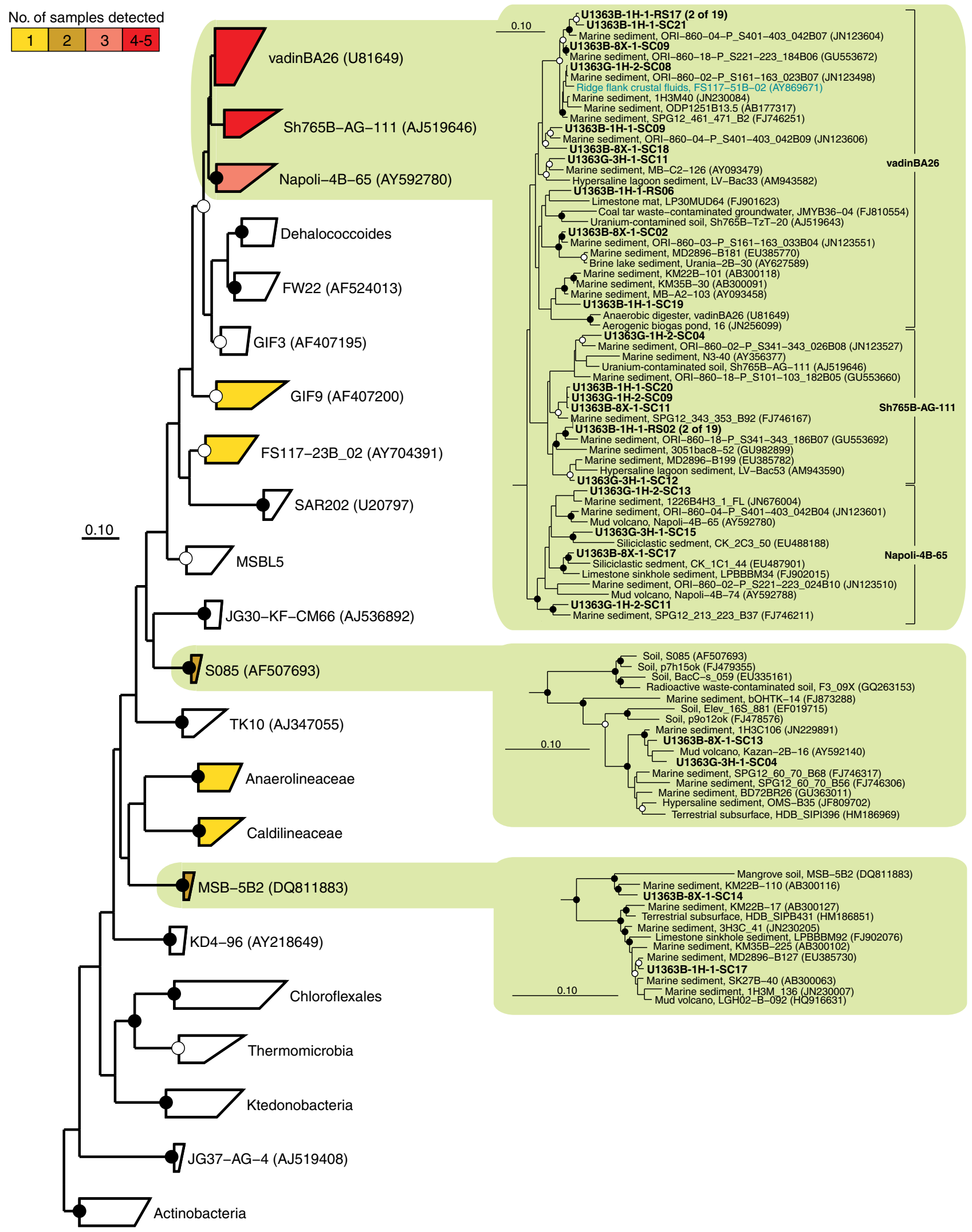


Figure F6. Phylogenetic relationships of Grizzly Bare sediment small subunit ribosomal RNA gene clones related to the Miscellaneous Crenarchaeotal Group. Group names are consistent with the previous naming scheme outline (Kubo et al., 2012). Blue outlines and text indicate lineages previously recovered from the Juan de Fuca Ridge flank basement environment (Cowen et al., 2003; Huber et al., 2006b, Nakagawa et al., 2006; Orcutt et al., 2011b; Jungbluth et al., 2013). Cultivated Crenarchaeota were used as an outgroup. See Figure F4 for symbol definitions and other information.

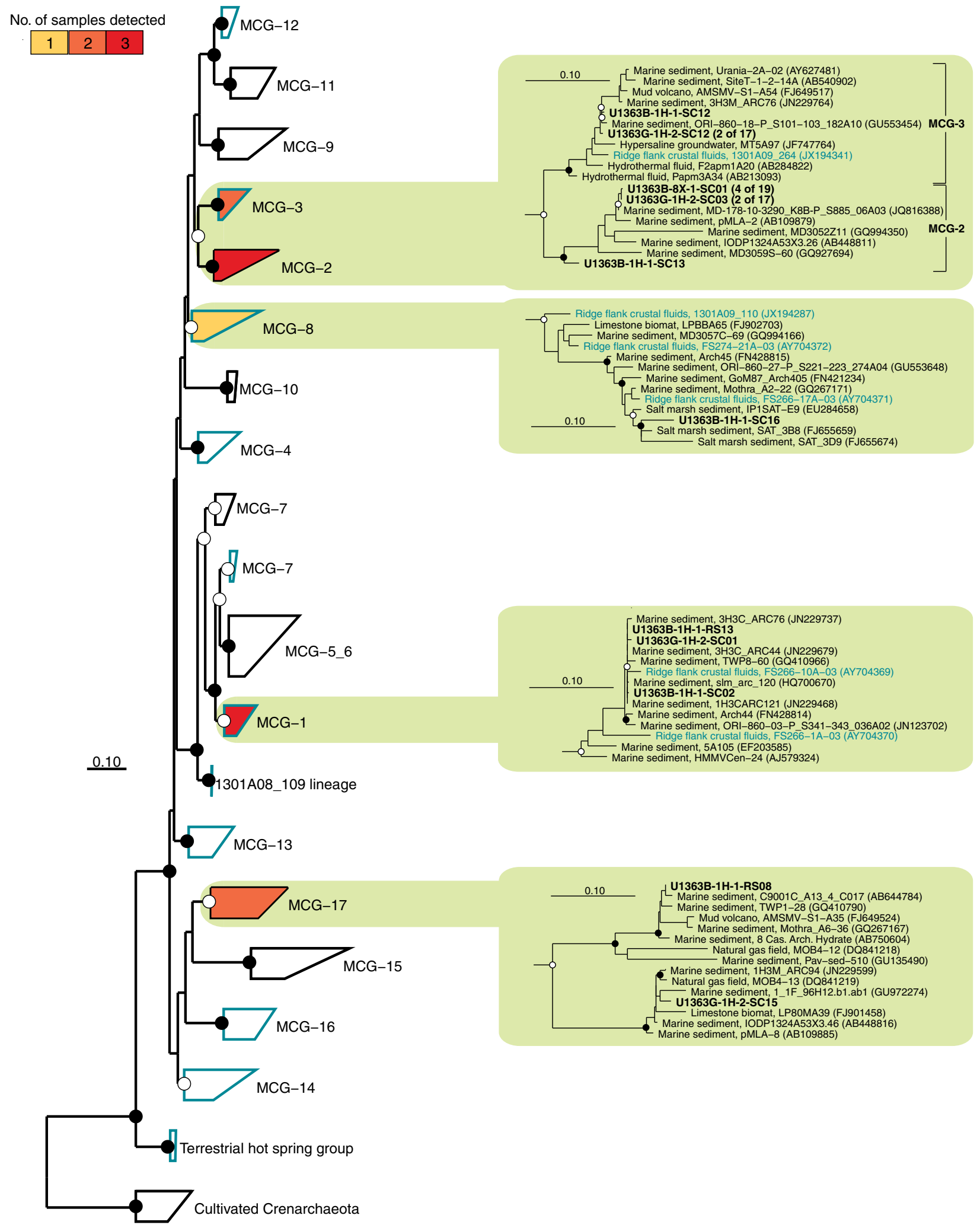


Figure F7. Phylogenetic relationships of Grizzly Bare sediment small subunit ribosomal RNA gene clones related to (A) the Salinimicrobium lineage within the bacterial phylum Bacteroidetes and (B) the Trichocomaceae lineage of eukaryotic Fungi. Cultivated members of the Bacteroidetes in A and Fungi in B were used as outgoups (data not shown). Scale bars correspond to (A) 0.1 and (B) 0.01 substitutions per nucleotide position. See Figure F4 for symbol definitions and other information.

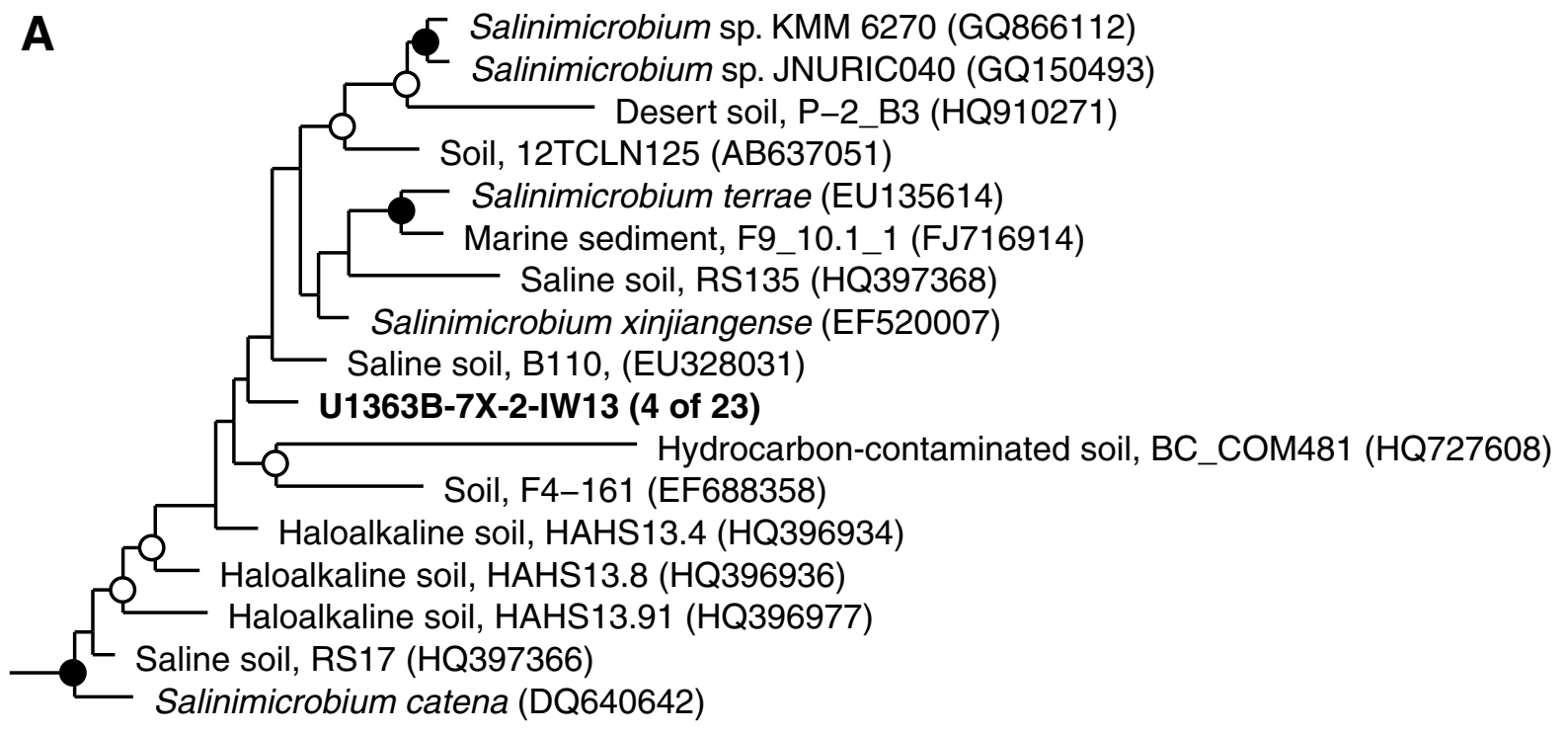

0.10

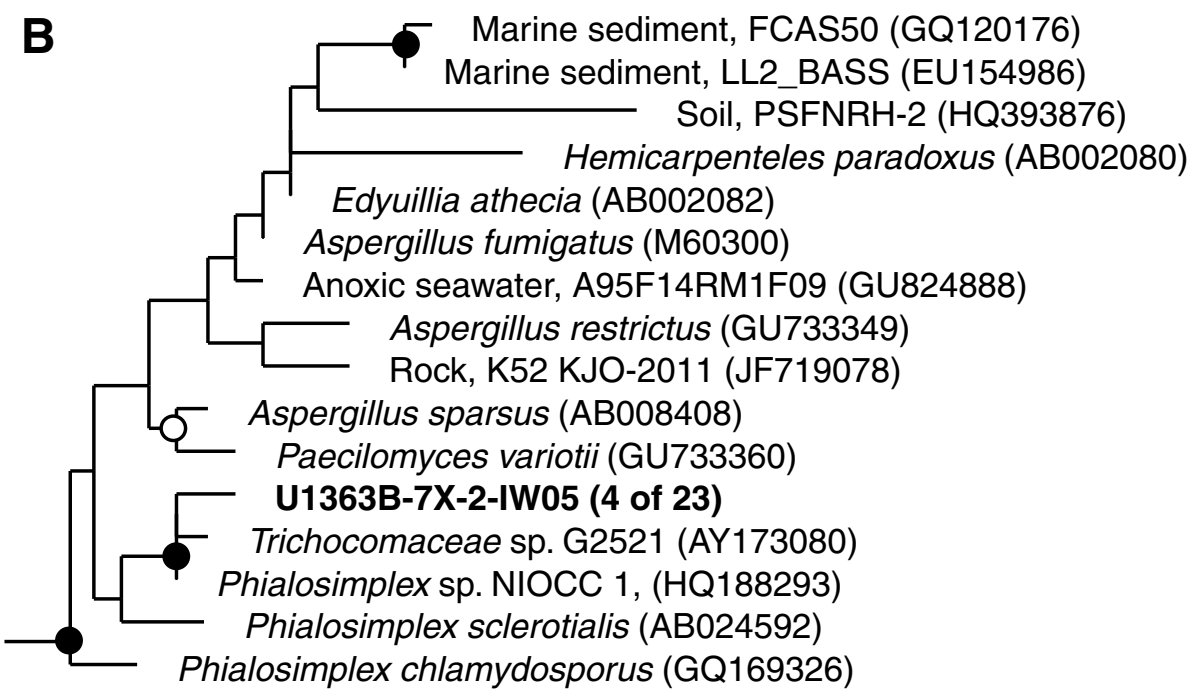

0.01 
Figure F8. Phylogenetic relationships of Grizzly Bare sediment small subunit ribosomal RNA gene clones related to the candidate bacterial phyla (A) BRC1, (B) OPB41, and (C) TA06. Lineages in blue text are related to candidate bacterial phyla OPB41 and TA06 and were previously recovered from Juan de Fuca Ridge flank Baby Bare fluids (Huber et al., 2006b). Cultivated Thermus and Deinococcus in A, a variety of cultivated Bacteria in B, and cultivated Caldithrix in C were used as outgoups (data not shown). See Figure F4 for symbol definitions and other information. (Continued on next page.)
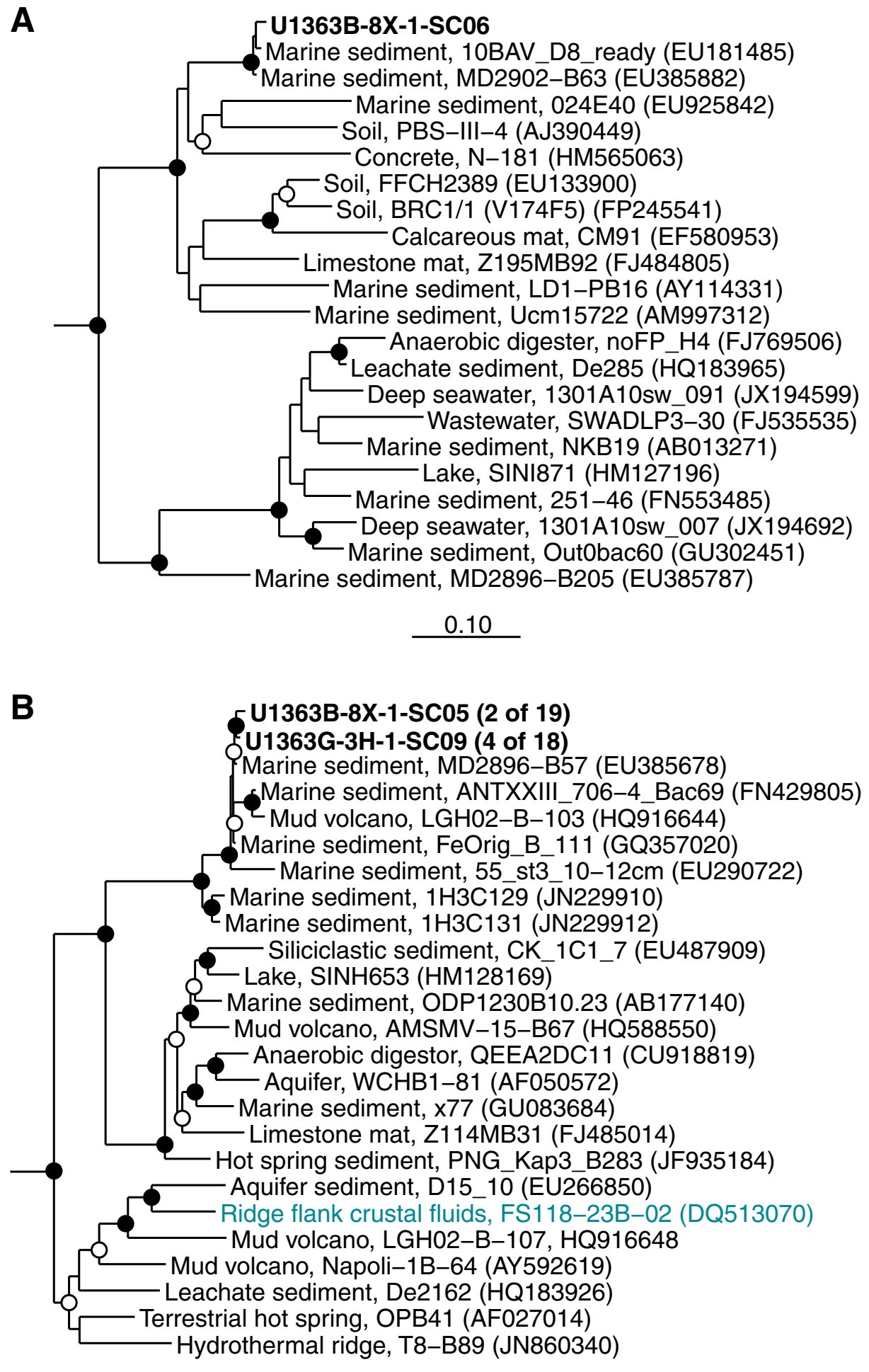

0.10 
Figure F8 (continued).

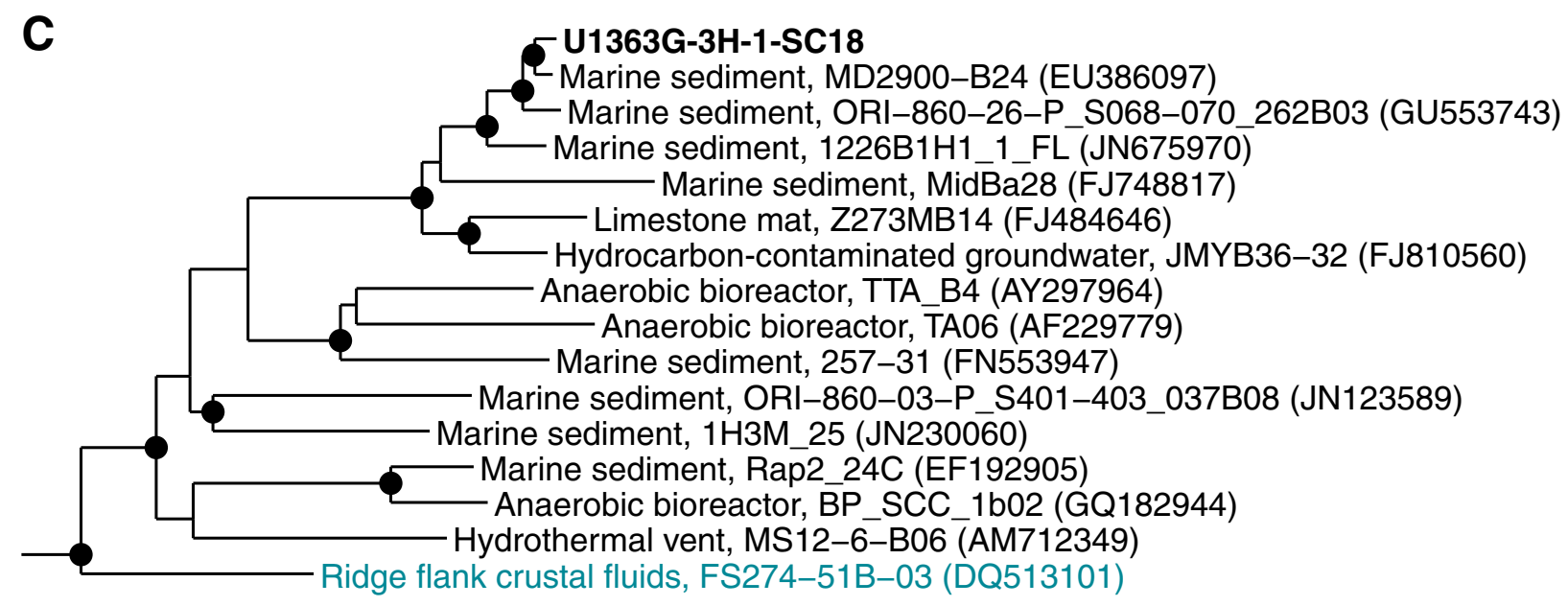


Figure F9. Microbial community relatedness between Hole U1363B sediment or fluid-derived small subunit ribosomal RNA (SSU rRNA) gene clones from each individual sample collected clustered in to operational taxonomic units (OTUs) at (A) 99\% or (B) 97\% similarity cut-off values. Hole U1363G sediment-derived SSU rRNA gene clones from both samples clustered in to OTUs at (C) $99 \%$ or (D) $97 \%$.

A

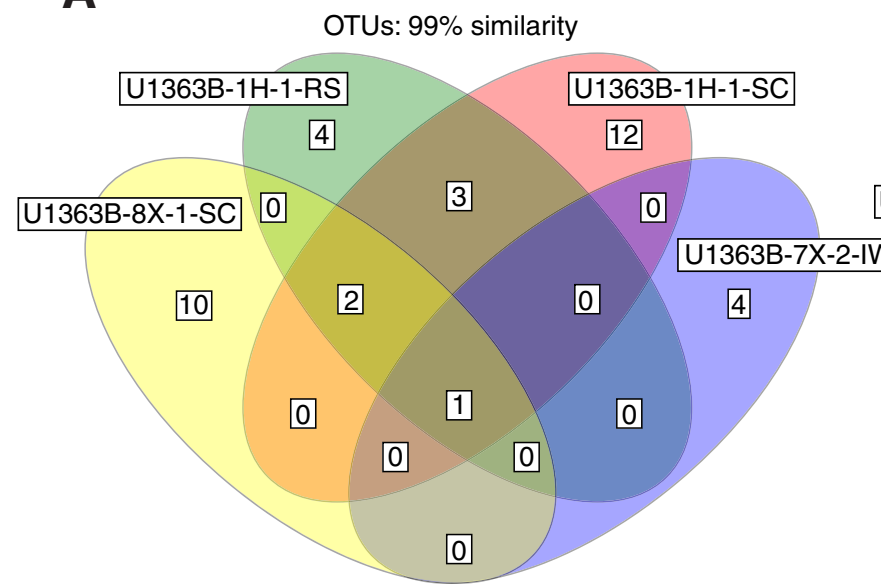

C

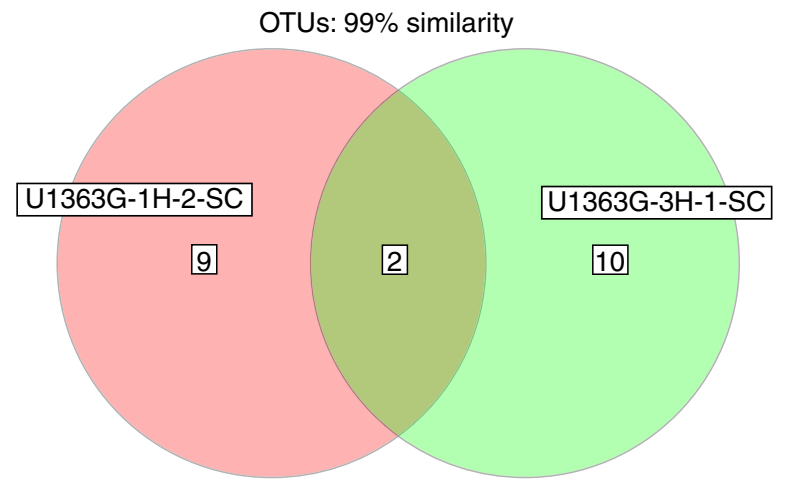

B

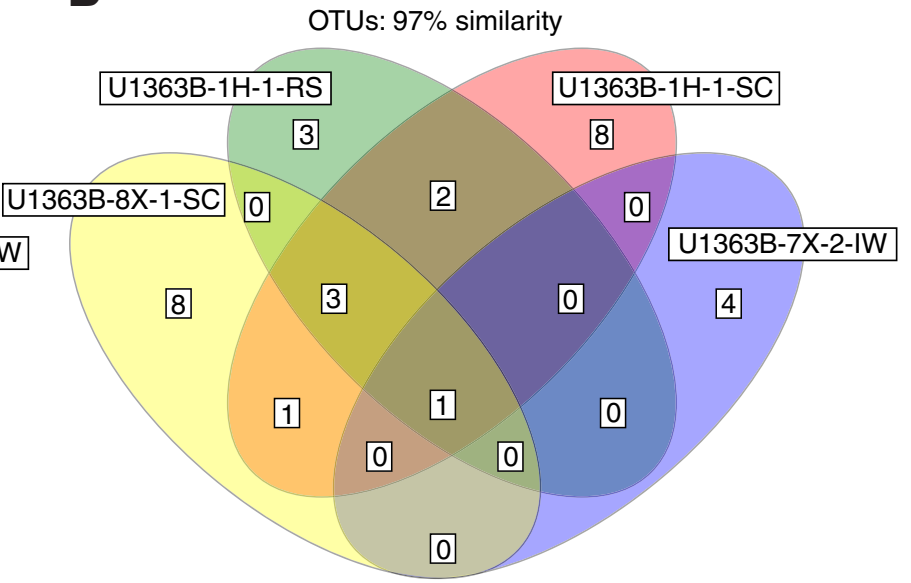

D

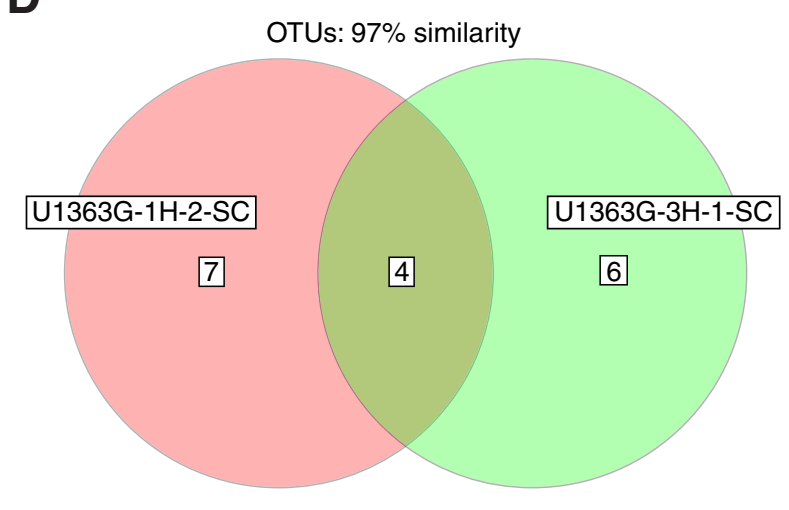


Figure F10. Microbial community relatedness between Hole U1363B and U1363G shallow sediment-derived small subunit ribosomal RNA (SSU rRNA) gene clones from each individual sample collected clustered into operational taxonomic units (OTUs) at (A) 99\% or (B) 97\% similarity cut-off values. Hole U1363B and U1363G deep sediment-derived SSU rRNA gene clones from each individual sample clustered in to OTUs at (C) $99 \%$ or (D) 97\% similarity cut-off values.

A

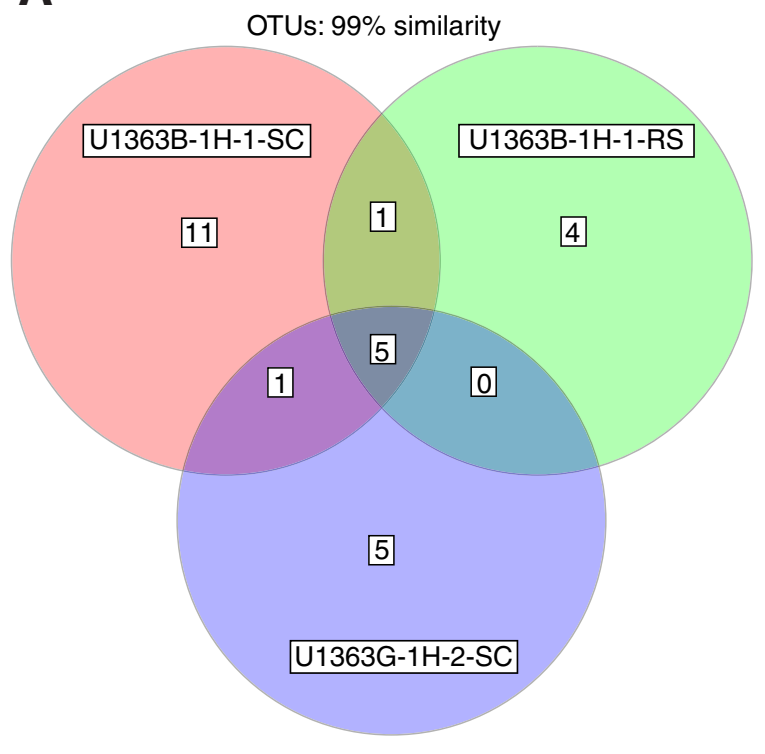

C

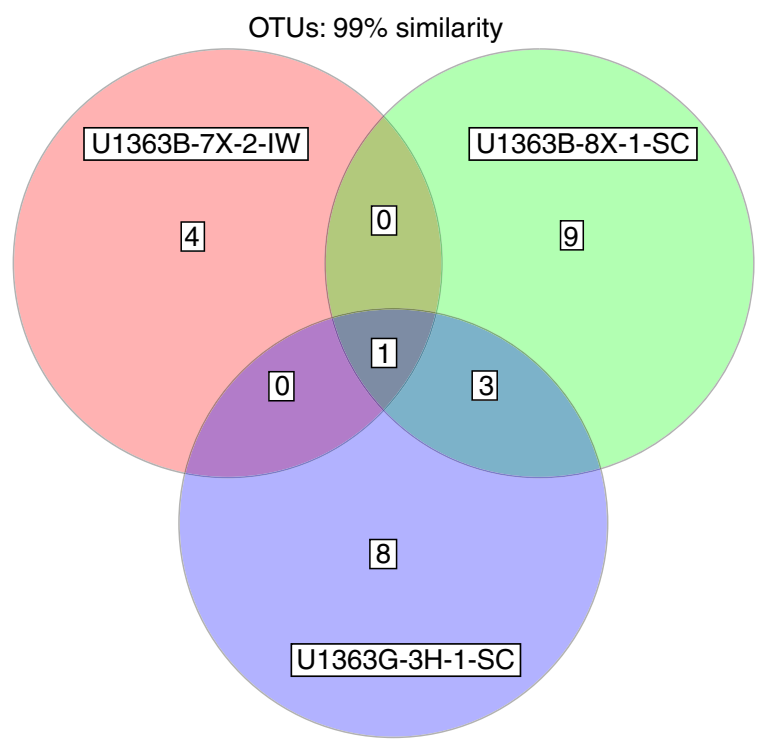

B

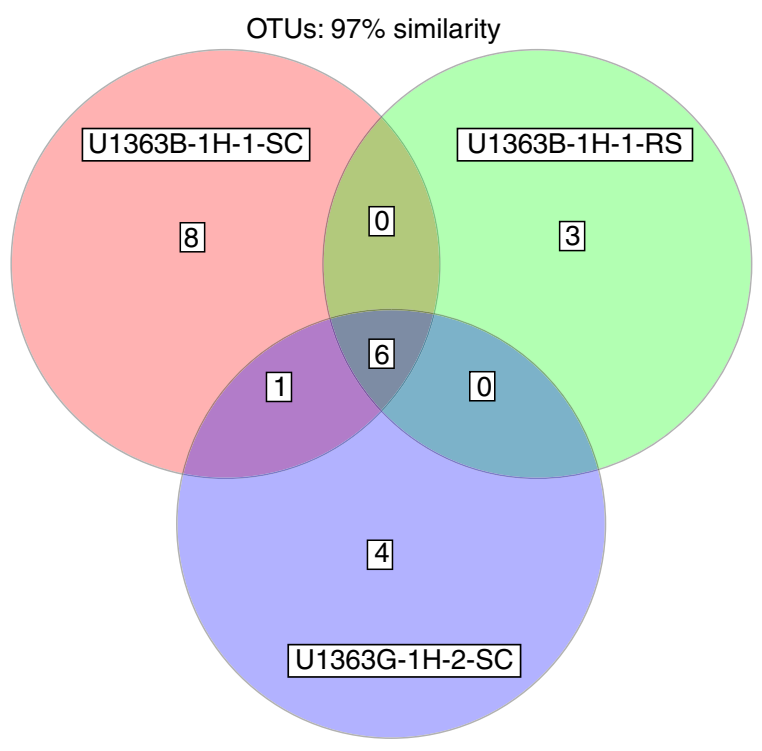

D

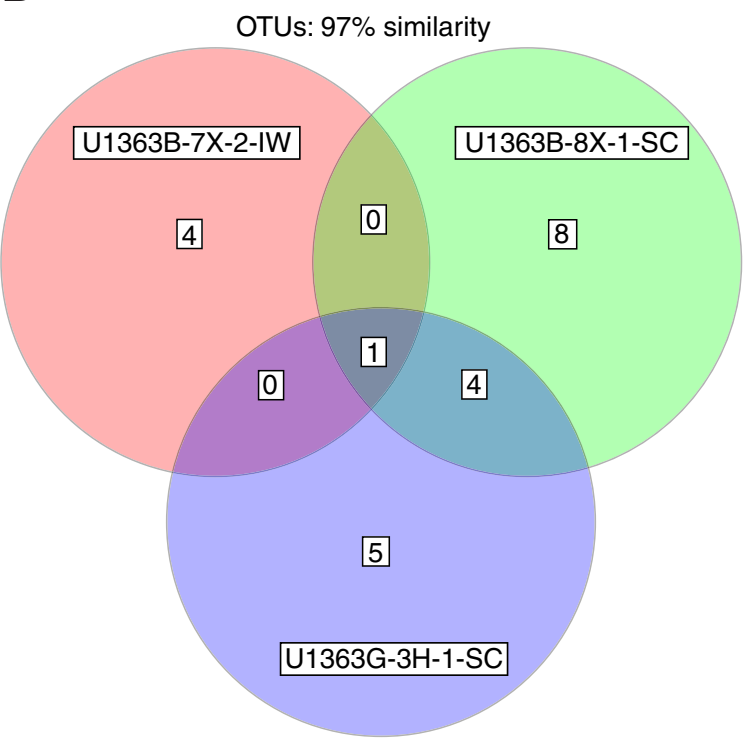


Figure F11. Microbial community relatedness between Hole U1363B and U1363G squeeze cake-derived small subunit ribosomal RNA (SSU rRNA) gene clones from each individual sample clustered in to operational taxonomic units (OTUs) at (A) 99\% or (B) 97\% similarity cut-off values. Hole U1363B interstitial water and extraction control-derived SSU rRNA gene clones from both samples clustered in to OTUs at (C) 99\% or (D) $97 \%$ similarity cut-off values.

A

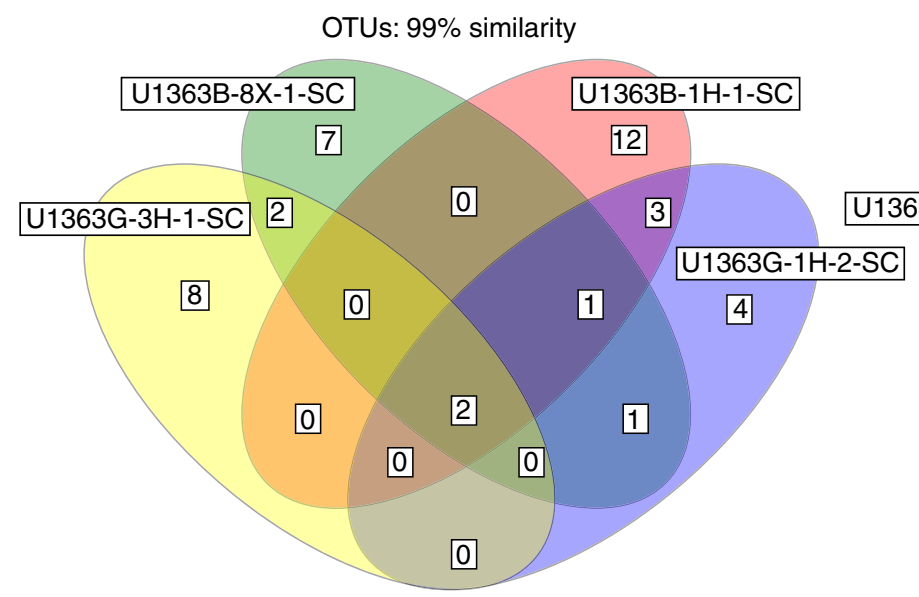

C

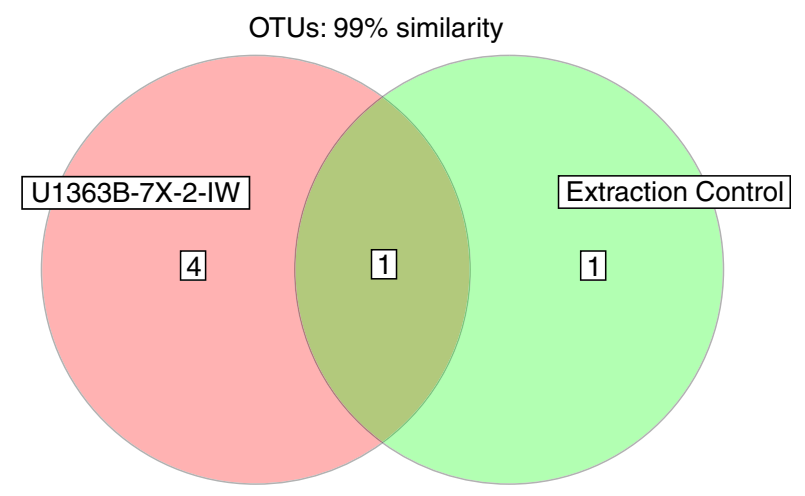

B
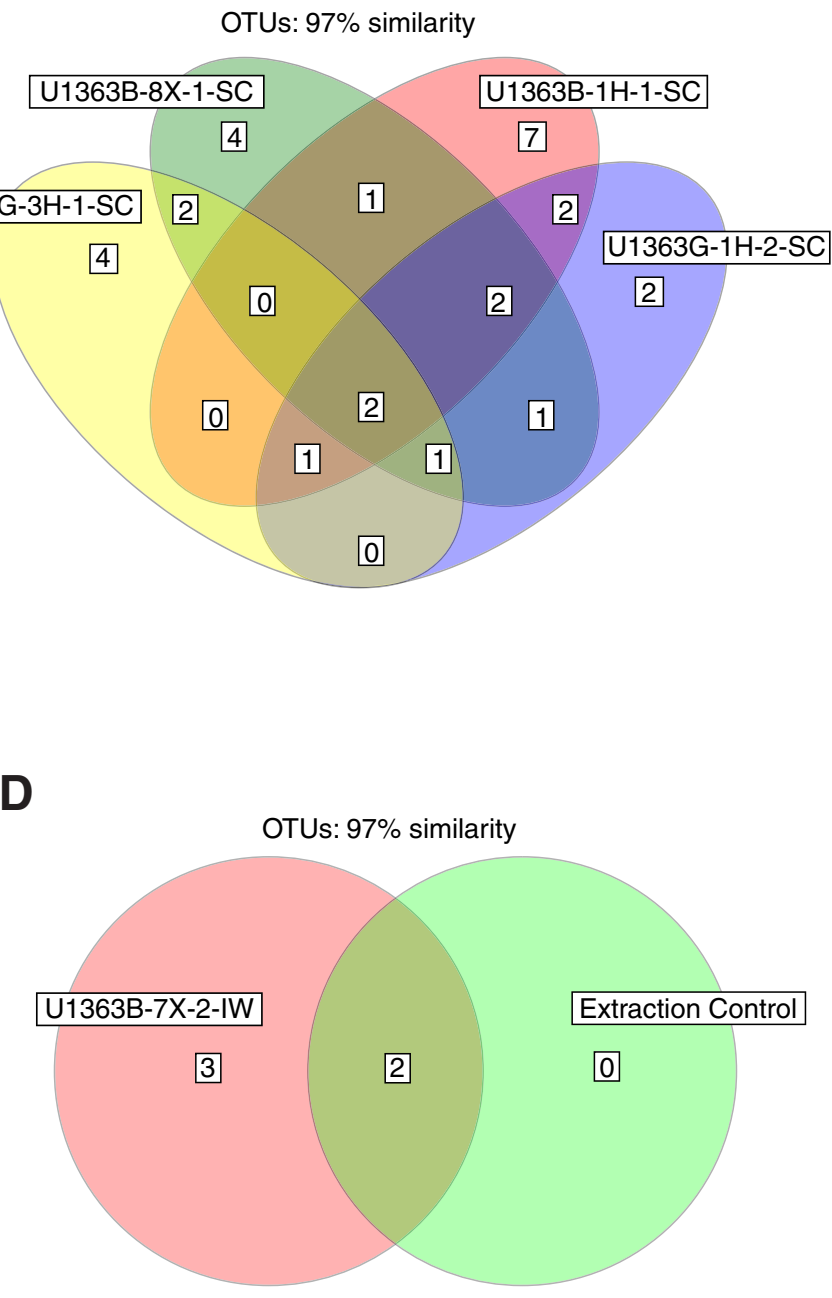
Table T1. Analyzed samples, Holes U1363B and U1363G.

\begin{tabular}{|c|c|c|c|c|c|c|}
\hline $\begin{array}{l}\text { Core, section } \\
\text { interval }(\mathrm{cm})\end{array}$ & $\begin{array}{l}\text { IODP sample } \\
\text { identifier }\end{array}$ & $\begin{array}{l}\text { Absolute depth } \\
\text { (mbsf) }\end{array}$ & $\begin{array}{l}\text { Distance from } \\
\text { basement }(m)\end{array}$ & Sample type & $\begin{array}{l}\text { Total DNA } \\
\text { recovered } \\
\text { (ng) }\end{array}$ & Clone prefix \\
\hline \multicolumn{7}{|l|}{ 327-U1363B- } \\
\hline $1 \mathrm{H}-1,0-10$ & CAKE2410281 & $0.00-0.10$ & $17.00-16.90$ & Squeeze cake & 153.3 & 1363B1H1_SC \\
\hline $1 \mathrm{H}-1,130-140$ & OTHR2409681 & $1.30-1.40$ & $15.70-15.60$ & Sediment & 359.8 & 1363B1H1_RS \\
\hline $7 X-2,125-145$ & LIQ2412791 & $45.25-45.45$ & $11.75-11.55$ & Interstitial pore water & 8.9 & 1363B7X2_IW \\
\hline $8 X-1,130-150$ & CAKE2414001 & $48.80-49.00$ & $8.20-8.00$ & Squeeze cake & 128.3 & 1363B8X1_SC \\
\hline \multicolumn{7}{|l|}{ 327-U1363G- } \\
\hline $1 \mathrm{H}-2,126-136$ & CAKE2425971 & $2.76-2.86$ & $14.24-14.14$ & Squeeze cake & 46.6 & 1363G1H2_SC \\
\hline $3 \mathrm{H}-1,140-150$ & CAKE2428901 & $17.40-17.50$ & $<1$ & Squeeze cake & 295.6 & 1363G3H1_SC \\
\hline
\end{tabular}

Basement depths of 57.0 and 17.0 mbsf were used for Holes U1363B and U1363G, respectively (Expedition 327 Scientists, $2011 \mathrm{~b}$ ). Total DNA recovered from control was $5.2 \mathrm{ng}$. Most of Core 327-U1363G-3H is flow-in (Expedition 327 Scientists, 2011b). 
Table T2. Abundance and identity of small subunit ribosomal RNA gene clones recovered from Grizzly Bare sediment samples, Holes U1363B and U1363G. (Continued on next page.)

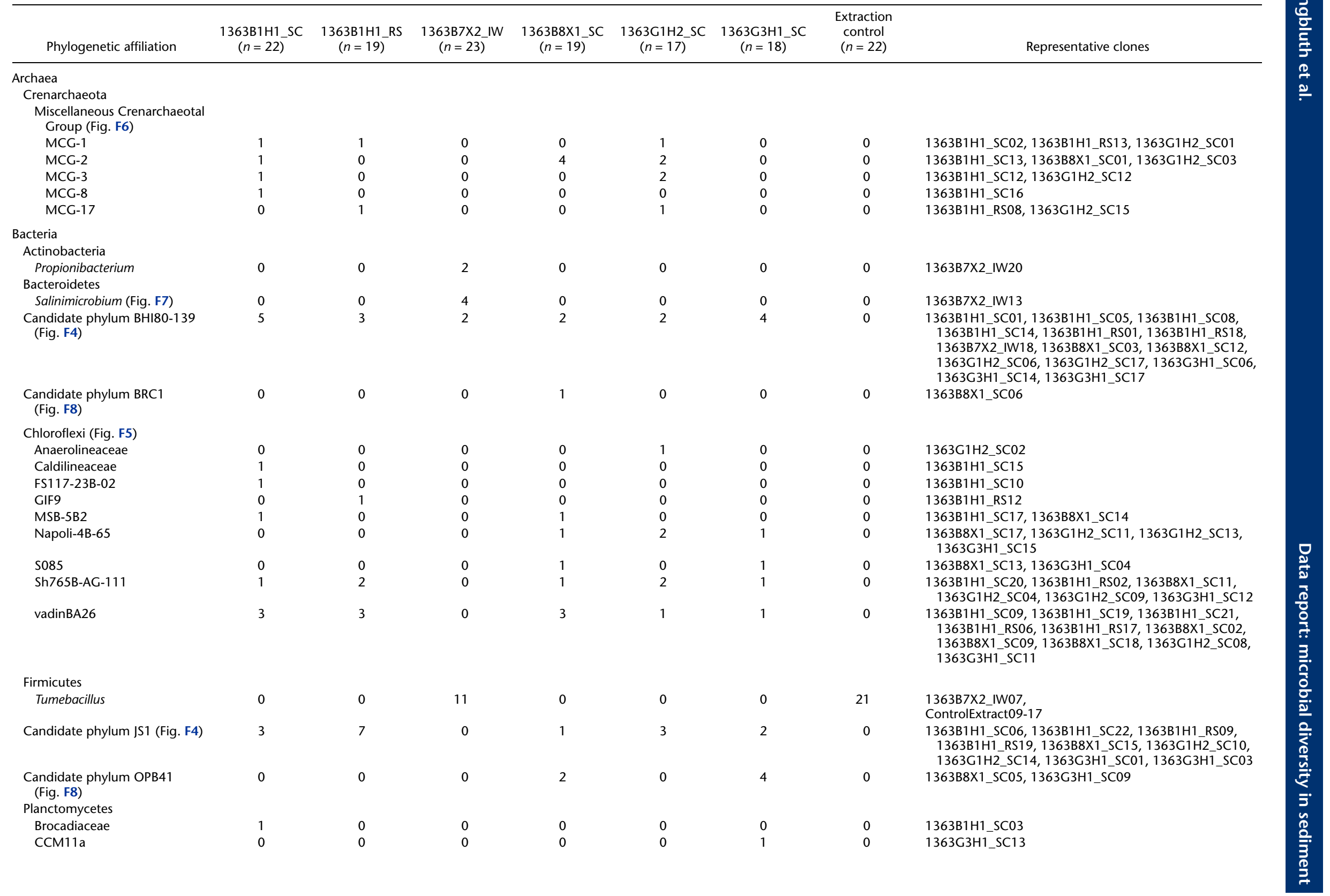




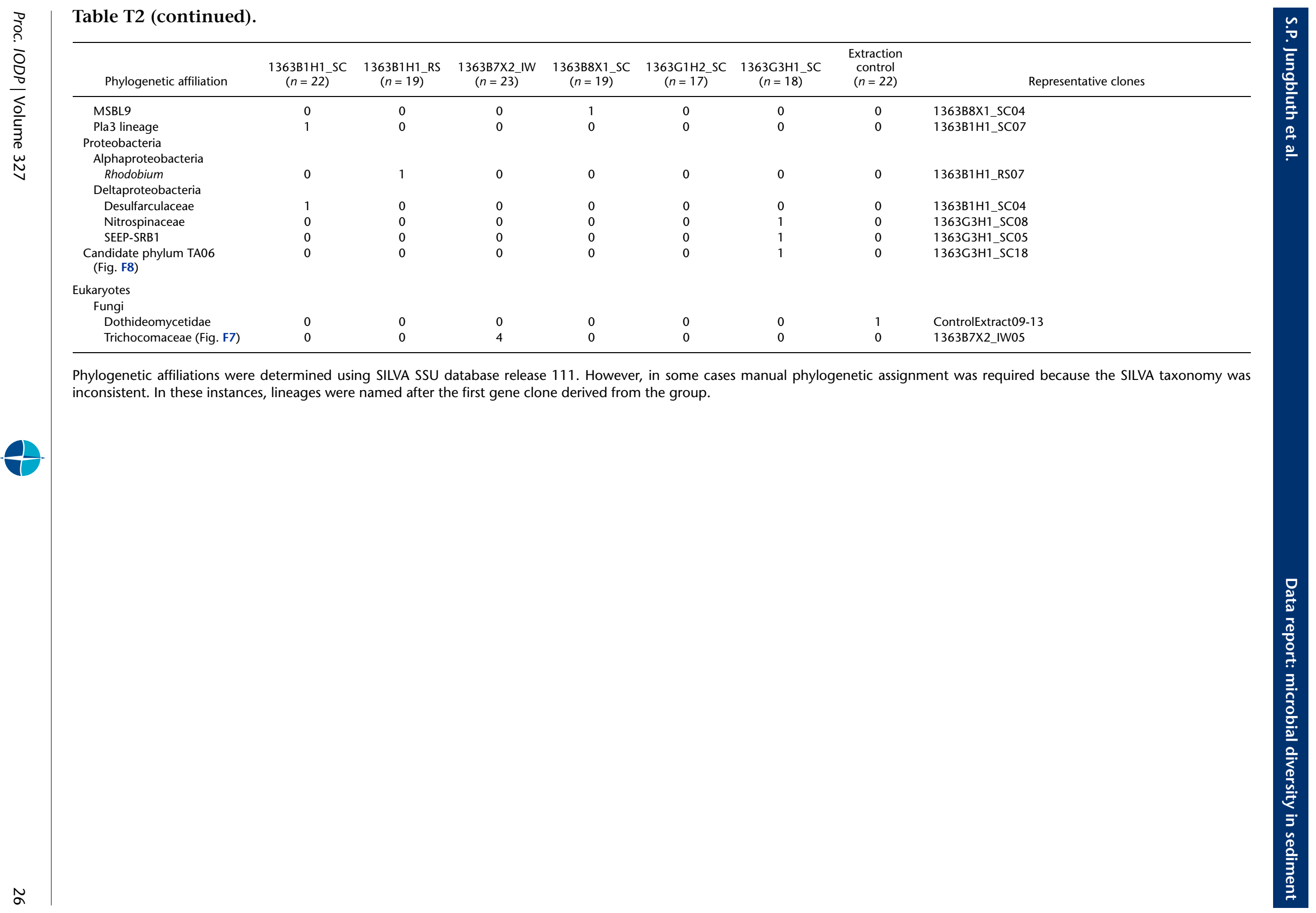


Table T3. Microbial richness and evenness in Grizzly Bare sediment samples, Holes U1363B and U1363G.

\begin{tabular}{|c|c|c|c|c|c|c|c|c|}
\hline Measure & $\begin{array}{l}\text { Similarity } \\
\text { cutoff }\end{array}$ & 1363B1H1_SC & 1363B1H1_RS & 1363B7X2_IW & 1363B8X1_SC & 1363G1H2_SC & 1363G3H1_SC & $\begin{array}{c}\text { Extraction } \\
\text { control }\end{array}$ \\
\hline $\begin{array}{l}\text { Number of sequenced } \\
\text { clones }\end{array}$ & & 21 & 19 & 23 & 17 & 14 & 17 & 21 \\
\hline \multirow{2}{*}{ Observed OTUs } & $99 \%$ & 18 & 10 & 5 & 13 & 11 & 12 & 2 \\
\hline & $97 \%$ & 15 & 9 & 5 & 13 & 11 & 10 & 2 \\
\hline \multicolumn{9}{|l|}{ Estimated OTUs (Chao1) } \\
\hline & $99 \%$ & 78 & 14 & 5 & 41 & 18 & 24 & 2 \\
\hline & $97 \%$ & 33 & 12 & 5 & 41 & 18 & 15 & 2 \\
\hline \multicolumn{9}{|l|}{ Simpson's evenness index } \\
\hline & $99 \%$ & 0.02 & 0.14 & 0.27 & 0.05 & 0.03 & 0.06 & 0.90 \\
\hline & $97 \%$ & 0.04 & 0.15 & 0.27 & 0.05 & 0.03 & 0.08 & 0.90 \\
\hline \multicolumn{9}{|l|}{ Shannon diversity index } \\
\hline & $99 \%$ & 4.26 & 2.53 & 1.45 & 3.47 & 3.29 & 3.15 & 0.31 \\
\hline & $97 \%$ & 3.39 & 2.33 & 1.45 & 3.47 & 3.29 & 2.66 & 0.31 \\
\hline
\end{tabular}

OTU = operational taxonomic unit.

Table T4. Summary of microbial community structure comparisons, Hole U1363B and U1363G.

\begin{tabular}{|c|c|c|}
\hline \multirow[b]{2}{*}{ Comparison } & \multicolumn{2}{|c|}{$\begin{array}{l}\text { Significance of UniFrac } \\
\text { metric (corrected p-value) }\end{array}$} \\
\hline & Weighted & Unweighted \\
\hline $1363 B \times 1363 G$ & 0.14 & $\leq 0.01$ \\
\hline Surface $\times$ deep & $\leq 0.01$ & $\leq 0.01$ \\
\hline 1363B1H1_SC × 1363B8X1_SC & 1.00 & 1.00 \\
\hline 1363B1H1_SC $\times$ 1363G1H2_SC & 1.00 & 1.00 \\
\hline 1363B1H1_SC × 1363G3H1_SC & 0.96 & 0.06 \\
\hline 1363B8X1_SC $\times 1363 \mathrm{G} 1 \mathrm{H} 2$ _SC & 1.00 & 1.00 \\
\hline 1363B8X1_SC × 1363G3H1_SC & 0.66 & 0.60 \\
\hline 1363G1H2_SC $\times 1363 \mathrm{G} 3 \mathrm{H} 1$ _SC & 0.06 & 0.06 \\
\hline 1363B1H1_SC × 1363B1H1_RS & 0.87 & 0.80 \\
\hline 1363B7X2_IW $\times$ extraction control & 0.02 & $<0.01$ \\
\hline
\end{tabular}

